Portland State University

PDXScholar

1982

\title{
Involvement, social class and attrition in higher education : the case of the stop out
}

Terrence Scott Daugherty

Portland State University

Follow this and additional works at: https://pdxscholar.library.pdx.edu/open_access_etds

Part of the Educational Sociology Commons, and the Higher Education Commons Let us know how access to this document benefits you.

\section{Recommended Citation}

Daugherty, Terrence Scott, "Involvement, social class and attrition in higher education : the case of the stop out" (1982). Dissertations and Theses. Paper 3190.

https://doi.org/10.15760/etd.3181

This Thesis is brought to you for free and open access. It has been accepted for inclusion in Dissertations and Theses by an authorized administrator of PDXScholar. Please contact us if we can make this document more accessible: pdxscholar@pdx.edu. 
AN ABSTRACT OF THE THESIS OF Terrence Scott Daugherty for the Master of Science in Sociology presented November 12, 1982.

Title: Involvement, Social Class and Attrition in Higher Education: The Case of the Stop out.

APPROVED BY MEMBERS OF THE THESIS COMMITTEE:

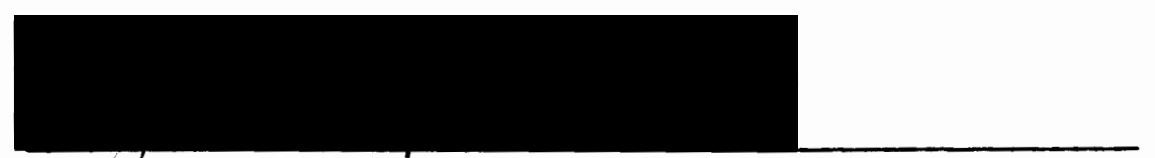

Jan Hajda, Chairman

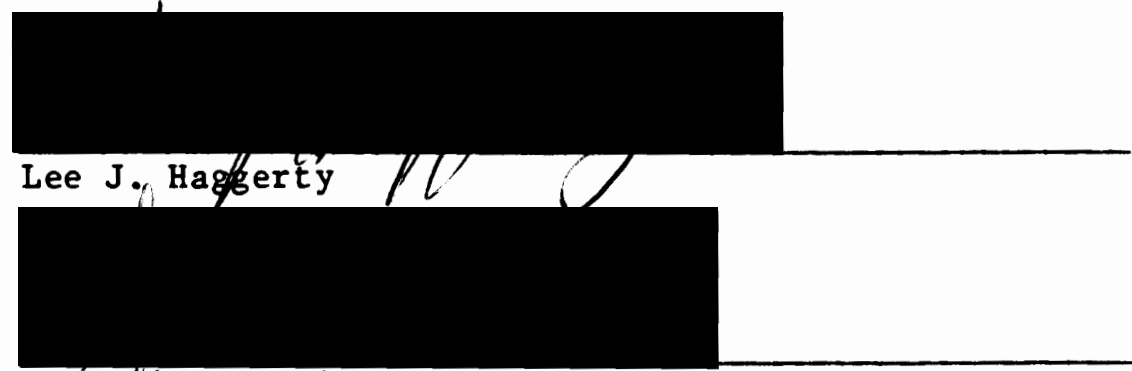

Frẹdefic H. Chino

This thesis tests the validity of three theories purporting to explain the attrition of stop outs - why students interrupt their studies with the intent to return to school. Data were gathered at two schools, Portland State University and Reed College. Two theories, those of social class and involvement, were tested at each school as contending explanations of attrition by path analysis of parsimonious models derived by factor analysis. These theories were found to explain little of the variance of attendance pattern (less than 4.3 percent) at either school. No particular lines of causation could be demonstrated at either school. The third theory, that of career planning, asserts 
that students interrupt their studies to re-evaluate their course of action upon recognizing that chances of employment in their field are not good. This proposition was supported by the data at Portland state University. 


\title{
INVOLVEMENT, SOCIAL CLASS AND ATTRITION \\ IN HIGHER EDUCATION : \\ THE CASE OF THE STOP OUT
}

$$
\text { by }
$$

TERRENCE SCOTT DAUGHERTY

A thesis submitted in partial fulfillment of the
requirements for the degree of

$$
\begin{gathered}
\text { MASTER OF SCIENCE } \\
\text { in } \\
\text { SOCIOLOGY }
\end{gathered}
$$

\author{
Portland State University
}


TO THE OFFICE OF GRADUATE STUDIES AND RESEARCH:

The members of the Committee approve the thesis of Terrence Scott Daugherty presented November 12,1982 .

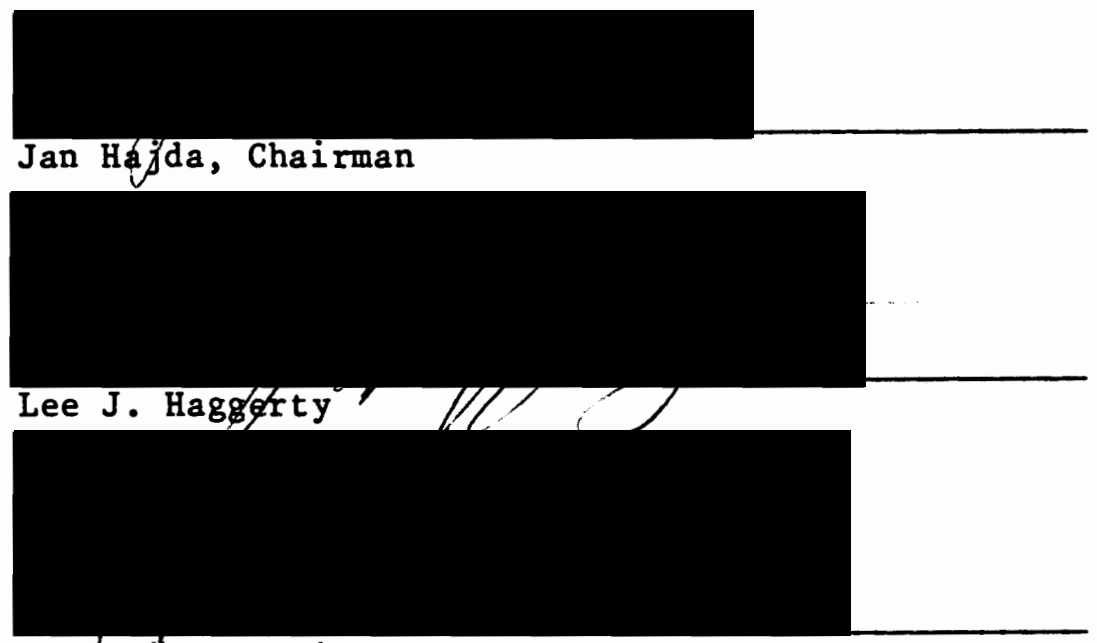

Frederíc H. Chino

\section{APPROVED :}

Charles Bolton, Head, Department of Sociology

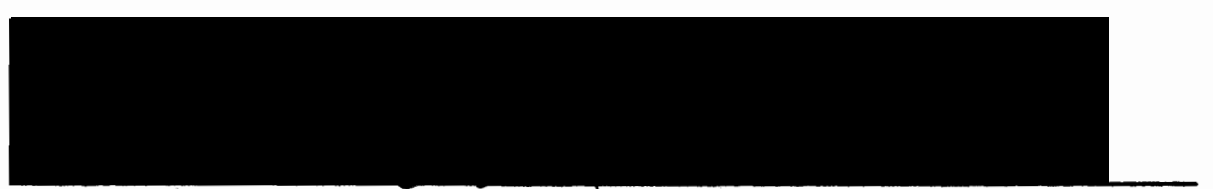

Stanley E. Rauch, Dean, Graduate Studies and Research 


\section{ACKNOWLEDG EMENTS}

I wish to express my appreciation to all the people who supported and directed the development of this thesis. I especially would like to thank Dr. Mary Kinnick and Dr. Dudman for their contributions during the data gathering stages of the project. The encouragement and efforts of Dr. Charles Bolton and Dr. Leonard Cain allowed me to successfully complete a task I otherwise would have set aside. I would like to thank my parents for their devotion, understanding, and support when I needed it. I would like to express my gratitude to Rita Fields, a talented friend who was there when I needed her. 
TABLE OF CONTENTS

PAGE

ACKNOWLEDGEMENTS . . . . . . . . . . . . . . . . . iii

LIST OF TABLES . . . . . . . . . . . . . . . . . . . . . vi

LIST OF FIGURES . . . . . . . . . . . . . . . . . . . vii

CHAPTER

I INTRODUCTION . . . . . . . . . . . . . . . 1

II REVIEW OF THE LITERATURE . . . . . . . . . . . . . 4

II I STATEMENT OF THE PROBLEM . . . . . . . . . . . . . 13

IV ME THODOLOGY . . . . . . . . . . . . . . . 21

V OBSERVATIONS • . . . . . . . . . . . . . . 28

Descriptions of the Institutions . . . . . . . 28

Portland State University

Reed College

Summary of Institution Descriptions

The Relevance of the Models........... 32

Portland State University

Reed College

Career Planning: An Alternative Explanation . . . 47

VI SUMMARY AND CONCLUSIONS . . . . . . . . . . . . . 54

Implications for Theory Construction . . . . . . . 57

Methodological Recomendations . . . . . . . 59 
PAGE

SOURCES CONSULTED . . . . . . . . . . . . . . . . . . 61 APPENDICES

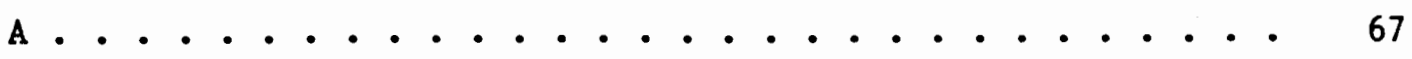

B............................ 73

C........................... 80 
LIST OF TABLES

TABLE

PAGE

I Sample Size, Response Numbers and Response Rate of

the Subjects Studied at PSU and Reed College . . . . . 22

II Response Count of the Restructured Attrition Variable. - 23

III Students Say Why They Leave PSU . . . . . . . . . . . 32

IV Varimax Rotated Factor Matrix of Social Class

Variables at PSU . . . . . . . . . . . . . 35

V Varimax Rotated Factor Matrix of Involvement

Variables at PSU . . . . . . . . . . . . . 36

VI Students Say Why They Leave Reed . . . . . . . . . . 40

VII Varimax Rotated Fact or Matrix of Social Class

Variables at Reed .................

VII Varimax Rotated Factor Matrix of Involvement

Variables at Reed ................ 43

IX Attrition of Stop Out Students by Major at PSU and Reed. 48

$X$ The Proportion of Students at PSU and Reed College who

Perceive Their Chances of Employment as Good . . . . . . 48

XI The Effect of the Perceived Chances of Employment on

Attendance Patterns of PSU Science Majors . . . . . . .

XII Gamma Correlations of the Perceived Chances of

Employment on the Attendance Patterns . . . . . . . 50

XIII Types of Orientations of Four Most Distinguishable

Student Subcultures . . . . . . . . . . . . . 51 


\section{LIST OF FIGURES}

1. Hypothesized Model of the Role of Social Class and Involvement in Explaining Attendance Patterns......

2. Hypothesized Model of Social Class and Involvement in Explaining Attendance Patterns at PSU . . . . . . . .

3. Actual Model of Social Class and Involvement in Explaining Attendance Patterns at PSU . . . . . . . .

4. Hypothesized Model of Social Class and Involvement in Explaining Attendance Patterns at Reed . . . . . . . . . 44

5. Actual Model of Social class and Involvement in Explaining Attendance Patterns at Reed ......... 


\section{CHAPTER I}

\section{INTRODUCTION}

In the near future, administrators and faculty in higher education will be increasingly confronted with prospects of a tapering off or decline in the birth rate and a decreasing proportion of the traditional age group ( 18 - 19 years) enrolling in colleges and universities (Capsules 1975). Such a situation has traditionally been dealt with by altering recruitment procedures to include students not previously a target (i.e., older persons, women with families, ethnic groups). This process may now need to be supplemented by a reduction in nonreturning students (Astin 1975). The term "nonreturning students" refers to those students admitted and enrolled in a degree program, who interrupt or stop their college attendance prior to achieving certification or a degree.

The plight of the nonreturning student is not just of concern to college administrators and faculty, but is important to students as well. A great deal of emphasis has been placed on college performance (grades) as a key to success. Research has demonstrated that college grade point average has little effect on future economic success, but rather it is college graduation that seems to be the key -- a degree tends to be a prerequisite for higher paying jobs (Lenning 1975). Higher education is relatively expensive and has few immediate economic returns for the student. Each quarter or semester is an investment of 
time and money in the student's future. A student who has been going to school for a year or more has a sizable stake in continuing that education. Yet, many students do leave school or, at the minimum, interrupt their studies.

On a more general level, the demands of complex, highly technological, democratic societies rely heavily on education systems to provide trained personnel to maintain and manage institutions. Higher education systems are a major means through which people become informed and achieve skills. Students who leave school prior to graduation may eventually pose problems for society. Many former students without a college degree may find themselves over-qualified for many positions and under-qualified for others. Such a situation is likely to create discontent among many of these people. An understanding of why students are leaving school would benefit college administrators, faculty, students and several others interested in society who are not directly related to the sphere of higher education.

The stop out is the primary focus of this research in attrition. The stop out also comprises a sizable proportion of nonreturning students. The stop out is the student that interrupts his or her studies, but intends to return to the same school.

This thesis is an exploratory research which attempts to address primarily the explanatory value of two contending models which have been purported to explain attrition in higher education - social class and involvement. These models will address the stop out students. A model which incorporates both the social class and involvement hypotheses is tested at two different schools, Portland State University and Reed College. A third alternative explanation suggested by the literature is 
also discussed: students are interrupting their education because they perceive it to no longer be "useful" in attaining their future career goa 1 s. 
CHAPTER II

\section{REVIEW OF THE LITERATURE}

The stop out is often confused with the drop out and transfer student under the title of nonreturning student in most of the literature on attrition in higher education. These stop outs comprise a sizable proportion of the short term statistics of nonreturning students. Term to term analysis of nonreturning students may treat transfers and students who are merely taking an extended break from their studies as drop outs. An analysis of a more longitudinal sort has revealed this point. Such information regarding the proportion of nonreturning students who are stop outs is available for the 1971 general student cohort at Portland State University (Daugherty 1976). This report displays the next four years' attendance pattern for this 1971 cohort in flow diagrams. For the first three of the four years studied stop outs do, in fact, comprise from 25 to 45 percent of the gross figure for nonreturning students from quarter to quarter, controlling for sumer break. Transfers were not distinguished from the remaining nonreturning students. Unfortunately, very little data are available which clearly distinguishes stop outs from drop outs and transfers.

Much of the literature on attrition does not relate directly to either the involvement or social class model. Most of the research appears to have skirted the issue. Much of the literature is concerned 
primarily with circumstances of students not returning to school or superficial descriptive material about these nonreturning students. One key variable which seems consistently excluded from studies of attrition is socioeconomic status or social class. Samuel Bowles and Herbert Gintis (1976) come close to discussing it, but stop short. They focus on the effect of social class on whether a student chooses or is able to go to college. They are interested in the selection criteria of higher education, how it acts to exclude many students or direct them into schools that vary in quality and generally how a low social class background excludes many students who are capable from the first step in achieving upward social mobility -- entrance to college. This thesis addresses the question of social class and higher education at the point where Bowles and Gintis leave off. Alexander Astin (1975) presents some interesting research which applies directly to attrition, but seems to discount socioeconomic status on questionable grounds. Social class variables have been shown to be closely related to all aspects of educational development but, oddly enough, seem to have been excluded from most studies of attrition. When mentioned, they have been buried in a myriad of other variables. This research is intended to address whether social class is a factor in explaining this attrition.

The question of when students leave school has been primarily concerned with the discovery of critical periods of student attendance when the likelihood of leaving school is highest. Iffert and clarke (1965), in a national research project, determined that only about eighty-five percent of college applicants actually enroll the same year that they apply. Of those who do enroll, the research tends to point to the freshman year as the most critical (Burgess 1969; Womack and 
McCluskey 1973; Daugherty 1976; Daugherty 1978). To be more specific, students are most likely to leave school after the first quarter and over the summer break of their freshman year. Subsequent summer breaks tend also to elicit disproportionate increases in nonreturning students. The first quarter of attendance at any school is likely to be tentative for many students - they are still considering the rewards and relevance of a college education in general, as well as education at any specific school. Those who complete their first academic year are likely to find time to reconsider their course of action over the summer break. They may become interested in other endeavors and may consider transferring to other schools. Every subsequent sumer break is likely to provide time to evaluate the potential costs and rewards of continuing to graduation at a specific school or doing something else. Some of the other research in attrition has addressed several basic demographic characteristics of students:

1. Sex - There is some ambiguity as to the differential attrition rates by sex. Burgess (1969) finds no apparent difference at one university, but Astin (1975) and others have found that females are slightly more likely to leave than are males (Kinnick and Huebner 1972). On the other hand, males are more likely to take longer to get their degree.

2. Marital status and dependents - Marriage is likely to be a factor leading to attrition, especially for women (Kinnick and Huebner 1972). Having children further increases the likelihood of leaving school for both men and women, but affects women nearly twice as much (Astin 1975). After the second year, the effect of marriage seems to be much less drastic (Burgess 1969). 
3. Attendance and entry status -- Those who have discontinued their attendance before are more likely to do so again. A similar pattern seems to hold for transfers (Burgess 1969).

4. Major - Attrition seems to be independent of ability to name a major upon entry as a freshman and is also independent of the division of study (Burgess 1969; Womack et al 1973).

Another approach to understanding attrition has been to ask students why they have left school. No clear priority seems evident. The students tend to give multiple reasons (Timmons 1972; Farine 1973; Florida International University 1975; Haas 1974; Astin 1975; Daugherty 1977; Daugherty 1979). The most prominent reasons given fall primarily into four general categories: academic, employment, financial and personal circumstances. Rather than just stating one reason for leaving, most students tend to give several such reasons.

It was from research at Portland State University (Daugherty 1977; Daugherty 1979) which addressed this question of why students were leaving school that the social class explanation of attrition seemed to emerge. Employment and financial circumstances were the reasons students most often gave as a major reason for leaving school. Although involvements were not a focus at the time of the research, the findings seemed to contradict some of the conclusions of Alexander Astin (1975). These contradictions were responsible for motivating this present reformulation of the problem.

From the diverse literature on college and university attrition, two major types of explanation seem to stand out: a lack of involvement and a lack of socioeconomic resources. The first stresses that students who lack involvements in campus life are more likely to leave school 
than those students who do not. The second emphasizes that those students from backgrounds which lack socioeconomic resources are more likely to leave school than those who are not.

Alexander Astin (1975) makes reference to an involvement theory which attempts to address student attrition in a coherent and concise manner. He stresses that

student involvement is a key factor in student persistence. A student's tendency to drop out of college is inversely related to the degree of direct involvement in the academic and social life of the institution. (pp. 175-176)

He draws this conclusion from the observation of the factors relating to attrition and persistence which he points out in his book. Clark, Heist, McConne11, Trow, and Youge (1972) make a similar statement. Involvement is considered to include three major areas: affiliations, employment, and aspirations and performance. One of the most important of the affiliations is place of residence. On-campus housing, particularly living in a sorority/fraternity or dormitory in the first two undergraduate years, will decrease the likelihood of leaving school (Astin 1975). Membership alone in fraternities and sororities, regardless of residence, may act to increase the likelihood of persistence. Intermingling with other students will help to reinforce positive academic values and discipline. Membership and participation in on-campus, extra-curricular activities and clubs also tends to decrease the probability that a student will leave school (Astin 1975; Kamens 1972). Activities which include other students tend to act as academic and emotional supports, as well as general means of expression. Students who have taken part in a systematic, advisory orientation tend to be much less likely to leave school (Burgess 1969; 
Astin 1975). This helps to inform students about programs and other alternatives and increases their capacities to find a niche in the system. They will at least be aware of the rules and appropriate procedures.

Employment is the second area of interest of the involvement model. Part-time employment is more conducive to persistence, whereas ful1-time employment is more likely to lead to dropping out than no employment at all. A job related to long range career goals is also likely to reduce the probability of a student leaving school. On-campus employment is also likely to reduce the chances of leaving school, especially in the case of work-study (Astin 1975). All these aspects of employment that might be conducive to persistence tend to put students into interaction with each other in an academic context, limiting the impact of external relationships to this academic enviroment.

The final area of focus of the involvement model is aspirations and performance. Previous performances help in setting future aspirations. The student's past indicators of academic ability (i. e., high school grade point average, SAT scores) tend to be the best indicators of persistence and attrition (Burgess 1969; Lavin 1974; Astin 1975). A sense of boredom in relation to class work may al so be interrelated with aspirations and expectations and is generally indicative of a lack of involvement.

Astin (1975) does look at socioeconomic indicators and states that they have been shown to be somewhat predictive of attrition, especially family income. But, he goes on to point out that when this social class variable is considered with other variables (student ability, parents' education and concern over finances) the relationship disappears. These 
variables appear to explain away most of the effect of socioeconomic background. 1

It is here that Astin appears to be making a grave error. He seems to think that these factors explain away family social class, when in actuality, they may be intricately tied up with it.

Compared with race, religion or ethnicity, social class is in most instances the main determinant of family experiences that contribute to or hinder a child's mental development and that will affect a child's progress in school (Havinghurst and Neugarten 1967, pp. 10-11).

Miller and Roby (1970) make a similar point. Social class affects family expectations for the child (Bronfrenbrenner 1966), language development (Hess and Shipman 1965), achievement values (Hyman 1966), and residence and high school peer values (Levine, Mitchell, and Havinghurst 1971; Wilson 1966). The high correlation between parents' education and family social class (income) is well known. Finally, it should be expected that a student's concern over finances would be closely related to the economic resource base from which the student operates (primarily family income). It almost seems as if Astin is trying to explain away some socioeconomic variables by using other socioeconomic variables that are less value-laden than social class or family income. All of these socioeconomic variables (family income, parents' education, immediate sources of student financial support and

$1_{\text {Astin }}$ derived his conclusions from data collected from a sample of randomly selected two and four year colleges and universities $(n=358)$. A sample of approximately 300 entering freshmen from each school $(n=101,000)$ filled out questionnaires. In four years (1972) these students were sent questionnaires again by first class postage. This was followed by a reminder and, a month later, by another questionnaire. The questionnaires were mailed to the 1968 addresses. The response rate was $40.9 \%(n=41,356)$. Much of the respondent bias was weighted out of the data using prior information on respondents and nonrespondents. 
their adequacy) must be analyzed as to their affect on attrition.

The initial decision as to whether to go to college is often social class based (Goode 1966; Milner 1972). The decision as to which college to attend is also somewhat influenced by social class (Clark, et al 1972). And once a student begins school, social class will again have an important effect via the availability of economic resources (Milner 1972).

A student who does not come from a high social class background is also likely to have to work on the side. This type of student is likely to take any job, whether part-time or full-time, on-campus or off-campus, academic related or not. The low economic resource student cannot pick and choose, but must take what he or she can get. Schooling may be just as important to this student as it is to the high economic resource student, but the demands of their biological systems (food, drink, shelter) and the costs of schooling require that they have an income, regardless of how it might affect their progress toward a degree.

Affiliations, stressed by Astin (1975), also may prove to be expensive. Dormitory and fraternity/sorority costs are of ten very high. Membership and participation in clubs and extra-curricular activities take time away from students, as well. If students are working, this time may be required for studies.

It was these two seemingly contradictory orientations toward explaining college attrition which lead to this exploratory research project testing the relative validity of these two contending explanations and the propositions which comprise them.

The literature suggests yet one other approach to the problem of 
attrition. This approach suggests that the student's expectations for employment upon receiving a degree in their area of study is an important factor to be considered in the explanation of attrition. Stinchcombe (1964) in a study of high school drop outs, has noted the importance of the students' expectations of the job market as a factor explaining high school attrition. The lower their expectations of employment with a high school degree, the more they are likely to drop out of high school. This may also be a factor in college. Students are often making pragmatic choices whether to continue school given their perceptions of future gains. Hillery $(1978 ; 1981)$ points to a problem in career planning in our colleges and universities. This is ultimately a problem of advising and counseling. Students are entering college with inflated aspirations in a potentially deflated job market. It is the role of counselors and advisors, according to Hillery (1978; 1981), to perceive and rectify such inflated aspirations. The student may then start with a realistic appraisal of the situation and not be frustrated by this information later, after some investment of time and money in a dead-end career. He argues that many students are lost to colleges and universities in just such a fashion -- the realization that they are preparing for a dead-end occupation. And when students leave school under such conditions it is often with a sense of betrayal and outrage. Hillery does not think that such attenuated mismatches between ideal career interests and a more pragmatic awareness of career opportunities in the students' areas of interest are necessary. They are a problem of advising and counseling. 


\section{STATEMENT OF THE PROBLEM}

The object of study of this thesis is the stop out student - the students who must interrupt their studies, but intend to return to the same schools. As noted in the review of the literature, this category is often confused with transfers to other schools and drop outs. The stop out has rarely been distinguished from the other groups in the literature, hence, the necessity of using the general literature on attrition to address this category and the reasons for their interruption of studies.

The primary problem of this study is, of course, the precipitating factors in attrition among college and university students. In particular, this thesis is an attempt to discuss and understand the roles of two seeming contradictory explanatory models which purport to articulate the causes of this attrition in regard to the stop out student. A third alternative will also be analyzed. Stinchcombe (1964) and Hillery (1978; 1981) have directed their attention to the rather pragmatic decisions which students make regarding their future employment upon graduation and regarding their perceptions of whether their education will provide them with greater employment opportunities. It should not be surprising that two explanations of the same problem are in apparent contradiction. Scientists and social scientists frequently disagree, offering two opposing perspectives (Kuhn 1970). 
Each argues in favor of his or her own conceptions of reality, often to the exclusion of the other perspectives. Occassionally there is room for a synthesis which incorporates the vital elements of both perspectives. 2 It is not argued that these two explanatory models are mutually exclusive. On the contrary, they may both be instrumental in explaining attrition. Each may be explaining attrition in a different fashion or type of population.

This thesis attempts to discuss not only the relative explanatory value of each model, but also their individual validity. Does an explanation of attrition in college fit into such a neat theoretical package? If it does, then which model best explains this phenomena or is there some important interplay between these models? Can these conclusions be generalized to significantly different colleges and universities with varied students and student environments? And if these models fail to explain much variation in attrition, what alternative focus may prove rewarding? These are the basic questions which this thesis attempts to answer.

The scope of this thesis has been limited to addressing the differences between the continuing student and what Astin (1975) has referred to as the stop out. The continuing student enrolls regularly and has a consistent progress toward a degree. The stop out progresses, but in an intermittent, stop and go, fashion. Continuing students are students who were in attendance fall quarter/semester 1977 and also in

2 Van Den Berghe (1969) attempts a synthesis of the order and conflict perspectives of sociology in "Dialactic and Functionalism: Toward a Theoretical Synthesis", as do Davis and Moore (1970), Davis (1970), Moore $(1970 \mathrm{a} ; 1970 \mathrm{~b} ; 1970 \mathrm{c})$ and Tumins $(1970 \mathrm{a} ; 1970 \mathrm{~b} ; 1970 \mathrm{c})$ in a series of discussions addressing stratification. 
attendance the next term. Students who were not in attendance the succeeding term, but who intended to transfer to another school were also classified as continuing students. Only one nonreturning student from each of the two schools studied actually did not intend to ever return to college. These two cases were discarded from the study.

The social class variables will be primarily socioeconomic and will be represented by the relatively standard indices of socioeconomic status (family income, education and occupation), as well as more contemporary personal indices of social class (personal income and employment). The specific social class variables are family (parents') income, level of education achieved by both parents, father's type of occupation (blue collar/white collar), personal income and employment.

Involvement tends to be of three sorts: affiliations, career-related employment, and academic involvement. Important affiliations include fraternity/sorority membership, on-campus extra curricular activities, on-campus clubs, on-campus residence and student friendships. Career-related employment is concerned with on-campus employment and whether the job is academic-goal related. Academic involvement addresses college grades and the intensity of the interests of students in their particular academic programs.

A third element, ability, might be more appropriately treated as a distinct variable, rather than as an aspect of either involvements or economic resources. It is likely to be related to both socioeconomic and involvement variables. This variable is represented by high school grades.

A fourth element, type of school, is concerned with how the differences in schools of higher education may affect attrition rates. 
Each school is likely to attract students from different backgrounds and with different interests. Clark and Trow (1966) have noted at least four ideal types of student "cultures" which operate under significantly different values and are directed at achieving different goals. These factors, in conjunction with distinct campus characteristics may alter the relative influence of the other variables: socioeconomic resources, involvements and ability. The relative influence of these three sets of variables are likely to be different from school to school and the rates of attrition are likely to vary accordingly. It is for this reason that the two schools to be analyzed are discussed separately.

The major interest of this thesis is to provide an adequate and meaningful explanation of why stop outs interrupt their progress toward achieving a degree. The literature has suggested at least two distinct and often contradictory explanations regarding attrition: social class and involvements. The relative efficacy of these models is the first focus of analysis. Their combined efficacy, including the causal validity of the direct and indirect propositions, is the second question to be addressed. Finally, an alternative explanation the literature and data suggest will be considered, especially should either or both the social class and involvement hypotheses prove inadequate. This hypothesis states that students are interrupting their education because they perceive it to no longer be "useful" in attaining their future career-employment goals.

The major propositions regarding attrition suggested by the literature review are presented graphically in Figure 1. Both the involvement and social class models have been combined in this display. Simplified, representative presentations of this display will provide 


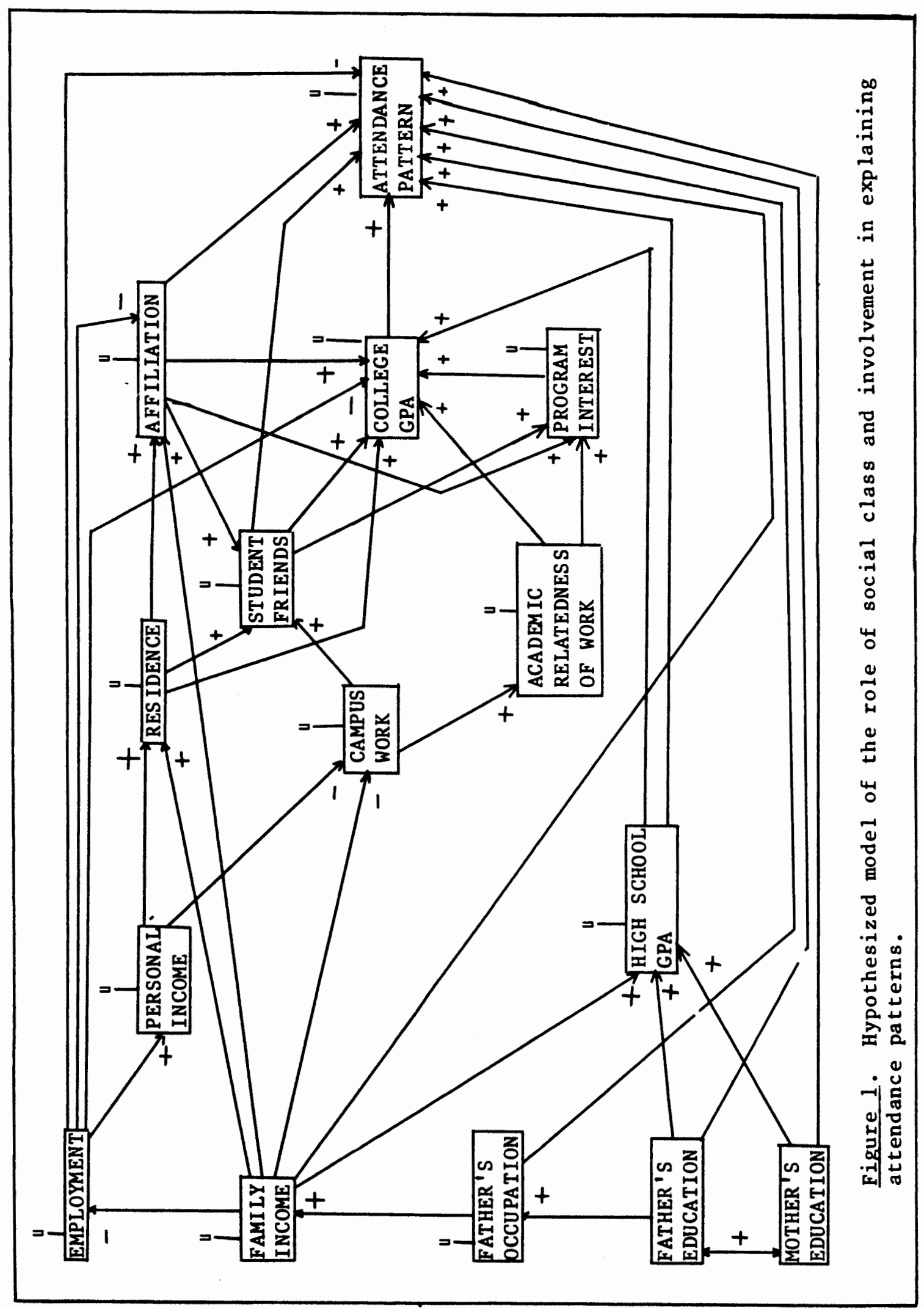


the test for the propositions, as well as the relevance of the two models individually and collectively. The ordering and actual testing of these relationships will be discussed more specifically in the next chapter. Clearly, it is argued that the social class variables both precede and affect the involvement variables, as well as the 1 ikelihood of continuing or stopping out directly. This is representative of the argument of social class impinging upon human relationships in a pervasive manner. Virtually all of the social class variables are denoted to have not only direct effects on attendance pattern, but indirect effects through each other and the involvement model variables. The socioeconomic variables are related in the fashion depicted by arrows. Their relation to the involvement variables and attendance pattern are also depicted. So too are the relations of the involvement variables to each other and attendance pattern.

Astin (1975) and others have argued that involvement in the college environment, in conjunction with an adequate skill leve1, will keep the student academically involved and working toward a degree. The same argument is here addressed to the stop out. Does living on-campus help build academic friendships and affiliations and does this translate into higher college grades, hence, continuing as a student? Does working on campus in an academic related field help one to meet student friends and enhance one's interest in a program of study? Does this translate into higher grades and continuing student status? And does having academic friends, affiliations, program interest and good grades have an independent effect on attendance pattern? Are high school grades actually indicative of college performance?

Bowles and Gintis (1976), as well as others, would argue that 
social class cannot so readily be excluded from such an analysis. Social class will impinge on these variables at virtually every point. Parental education and income, as well as being employed and the income so derived, radically affect one's capacity to live on campus and be involved in campus life. It takes money and time to get involved in campus life. Does it take money to live on campus? Does the education of our parents affect our high school and college performance and continuing student status? Does being employed detract from developing student friendships, affiliations and subsequent good grades? Does personal income and family income affect the likelihood of campus employment (this tends to be work-study)? Does being employed, family income, father's occupation, parents' education have a direct affect on attendance pattern? All the questions presented in this and the previous paragraph will be discussed in a later chapter along with the relative efficacy of the models, individually and collectively.

But the solution to the problem of attrition regarding stop outs may not end with this test. Other explanations not captured by this test must also be considered. The written responses of stop outs as to why they are interrupting their studies must also be taken into consideration, especially as they may illuminate or obscure the issues presented by the results of the test.

Finally, an alternative explanation has been suggested by the literature - attrition is a problem of career planning. Should Hillery (1978; 1981) and Stinchcombe (1964), discussed in the 1iterature review, be correct in their observations, it should be expected that those students with lower expectations for employment with a degree in their program of study will be more likely to stop out than those students 
with higher expectations for employment. In this instance, those divisions of study which are viewed by their participants as having poorer chances for employment upon graduation are likely to account for a disproportionate amount of the stop outs. The data to address this explanation is also available from the questionnaire and, hence, will also be analyzed in this thesis. 
CHAPTER IV

ME THODOLOGY

The information necessary for this research was obtained by questionnaire. Reliance must be placed on self-reported data. The "Buckley Amendment" makes it virtually impossible for schools of higher education to obtain social class information from students. Schools may not require students to provide any social class information about themselves or their families except in relation to financial need programs. Hence, schools generally do not request these data on even an optional basis.

The questionnaire was followed (after several weeks) with a reminder and second copy of the questionnaire, asking the student to fill it out and return it only if the first was not already responded to. The responses were carefully compared to avoid duplication. Addressed, post-paid envelopes were provided to the respondents for the return of completed questionnaires. Strict respondent anonymity was provided.

The questionnaire was sent to randomly selected (by social security number) samples of returning and nonreturning students at two colleges, which were likely to be significantly different in environment and student socioeconomic composition (Portland State University and Reed College). The research questionnaire was directed only to those students who had not graduated, had not already transferred out of the 
school studied and were full-time students (twelve hours of course work or more) in fall quarter/semester of the 1977-78 academic year. The samples were drawn from the student data bases of the respective schools.

The samples of nonreturning students include students in attendance fall quarter 1977 and not in attendance winter quarter 1978 at Portland State University (PSU) and in attendance first semester and not in attendance second semester at Reed.

Sample selections were made at the two institutions in terms of continuing and nonreturning students. The sample size, number of responses and response rate for the response subjects are presented in Table I. The response rates are about what might be expected from

\section{TABLE I}

SAMPLE SIZE, RESPONSE NUMBERS AND RESPONSE RATE

OF THE SUBJECTS STUDIED AT

PSU AND REED COLLEGE

\begin{tabular}{lcccc} 
School Samples & $\begin{array}{l}\text { Sample } \\
\text { Size }\end{array}$ & $\begin{array}{c}\text { Number of } \\
\text { Responses }\end{array}$ & $\begin{array}{c}\text { Response } \\
\text { Rates }\end{array}$ \\
\cline { 2 - 2 } PSU Continuing & 450 & & 259 & $57.6 \%$ \\
PSU Nonreturn & 276 & 95 & $34.4 \%$ \\
Reed Continuing & 450 & 222 & $49.3 \%$ \\
Reed Nonreturn & $83 *$ & 36 & $43.4 \%$ \\
& & &
\end{tabular}

previous research in attrition. The lower response rate of nonreturning students may be accounted for by the inclination of many students who have left school to be reluctant to return the questionnaire because they've moved, transferred, become involved in other interests or have some grudge against the school. Whatever their reasons for not returning the questionnaires, a few student characteristics (class level 
and sex of the respondent) were requested of the respondents to help control for response biases which might occur. The same requests were made of continuing students for the same reasons, to check for significant response biases.

The response rate of nonreturning students was lower than was hoped for. Only one confirmed drop out from each school bothered to return the questionnaire. It was also discovered that about one-third of the nonreturning students at both schools were neither drop outs nor stop outs, but intended transferring to another school. The dependent variable had to be redefined somewhat. Another variable, future academic plans, was utilized to restructure the data. The new attrition variable became attendance pattern (stop out and continuing students). The restructuring resulted in an increase in the number of continuing students through the inclusion of intended transfers and a marked decline in the number of nonreturning students because of this inclusion and the 1088 of several cases that were found to be unclassifiable in regard to the new attrition variable (intend to not return to college and other). The new sample response counts of the restructured data used in this research are displayed in Table II.

\section{TABLE II}

RESPONSE COUNT OF THE RESTRUCTURED

ATTRITION VARIABLE

$\begin{array}{lrrr}\text { Attrition Variable } & & \text { PSU } & \text { Reed } \\ \text { Continuing students } & 293 & 237 \\ \text { Stop Outs } & 49 & 14 \\ \text { Lost Cases } & 12 & 7\end{array}$

The representativeness of the responses to the original randomly 
selected sample was tested by use of the chi-square statistic at the .05 level of significance. The responses were not found to vary significantly from the randomly selected sample in regard to two known variables, sex and class level. What response biases that did occur in regard to these two variables involved the PSU and Reed nonreturning students. At PSU, freshmen tended to be somewhat over-represented and seniors somewhat under-represented amongst the responses. Females tended to be somewhat over-represented at Reed. None of these variations from the original samples were found to be statistically significant at the .05 level.

The test of the social class and involvement propositions will utilize path analysis. The confusion of lines of causation depicted in Figure 1 of Chapter III must first be simplified to a parsimonious construct. This was accomplished through the use of factor analysis. Measures of significance and correlation were also utilized.

Six social class and eight involvement variables were presented in Figure 1. These variables have been transformed to bivariate variables, utilizing median, or most meaningful point near the median, as the point of division. The six social class variables have been operationalized as: father's education (high school graduate/at least some college); mother's education (same); father's occupation (blue collar/white collar); family income (parents', less than or equal to $\$ 25,000$ a year/over $\$ 25,000$ ); personal income (self and spouse, less than or equal to $\$ 5,000 /$ over $\$ 5,000$ a year); and employment (not employed/employed). The eight involvement variables are also operationalized: affiliations (none/at least one membership); student friendships (proportion of friends who are students, few to some/ most to al1); residence 
(off-campus/on-campus or near-campus); campus work (off-campus/

on-campus); academic relatedness of work (none/partial to high); program interest (none to moderate/great); college GPA (less than or equal to 3.00 /over 3.00 ); and high school GPA (same). The dependent variable is attendance pattern (stop out/continuing).

The first manipulation of the data involved factor analysis to reduce the number of variables to be addressed in the path analytic schemes. Four factor analyses with varimax rotation were completed one for each of the variable complexes (social class and involvement) at each of the schools (Portland State University and Reed College) studied. The six social class variables were reduced at each school to the number of factors designated by the respective factor analyses. The highest factor loading variable for each factor became representative of that factor. Those variables not loading the highest on any factor were excluded from the path analysis at that school. The same procedure was used for the eight involvement variables. The paths of causation indicated in Figure 1 were recreated in a more parsimonious but representative fashion utilizing the respective factors derived from the factor analyses.

Path analysis is a powerful tool in the discussion of causation. Ideally, longitudinal data is most appropriate for path analysis; however, the data used here was cross-sectional. Care was taken to place the variables in the most appropriate order of sequence in order to construct a longitudinal framework of causation. Path analysis is effective in handling two principal tasks: (a) whether the social class variables work independent of or through the involvement variables and (b) showing the relative importance of the paths in accounting for these 
relationships. The total amount of variance explained by the social class and involvement variables, both independently and collectively, at each of the schools is important, but not the sole object of these tests. This amount of explained variance was provided by a $R^{2}$ derived from a multiple regression of the relevant independent variables on attendance pattern. The concern of these tests was to explain the variance of attendance patterns that exist at these two schools, as well as the amount of variance explained. Those paths with path coefficients equal to or exceeding .05 were kept as meeting the minimum criteria of meaningfulness. Paths not hypothesized but having an affect on the relationships were then included.

The chi-square measure of significance and Fisher's Exact Test were used to measure for significant variations between variables in cross tabulations. The .05 level of certainty was the criteria for the discussion of these cross tabulations in this research. The chi-square was the measure of first choice and Fisher's Exact Test was utilized for two by two tables with very small cell counts. Coefficients of correlation measure for the determination of strength of relationship in the discussion of cross tabulations.

The calculations for this research were computed by the Portland State University Honeywell computer system through an account initially provided by PSU's Office of Institutional Research. The software programming was by means of SPSS, Statistical Package for the Social Sciences (Nie, Hul1, Jenkins, Steinbrenner, and Bent; 1975).

A final source of data that was included in this analysis of the stop out was the qualitative response to the open-ended question, "Briefly state your major reason for leaving school", addressed to the 
nonreturning students at PSU and Reed. This kind of qualitative data, collected in the respondent's own words, is extremely useful in understanding the situation viewed from the perspective of those who experience it. Even though it is difficult to make comparisons among unique responses, these responses have been grouped in terms of their thematic similarities to provide a quantitative base for their analysis. The qualitative responses are provided in Appendices B \& C. 


\section{CHAPTER V}

\section{OBSERVATIONS}

\section{DES CRIPTIONS OF THE INSTITUTIONS}

The focus of this research was attrition in higher education. The research was conducted in two significantly different school environments, Portland State University and Reed College. Prior to any discussion of the findings of this research, it may be instructive to provide descriptions of these two very different schools.

\section{Portland State University}

PSU is a relative newcomer to the academic scene. It achieved college status in 1955. At the time of this research, PSU had approximately 15,000 student enrollees. Nearly 6,000 enrollees were part-time students. PSU is an urban university located in the heart of Oregon's largest city, Portland. PSU's campus life is minimal because there is very little on-campus housing. It is primarily a commuter school. Its student body is a mixed group of transfers, new students from high school and older students returning to school after a long absence. PSU probably has the most diverse student body of any major college in the state. It tends to draw the bulk of its student body from the local community giving what little campus atmosphere there is some local flavor.

Nearly half (48.2\%) of the PSU respondents received some parental 
economic support for their college education, but the dominant sources of economic support were personal savings ( $55.6 \%$ ) and employment (59.1\%). Another 14.6 percent received work-study funds. Only a small proportion of the employment was on-campus (18.6\%).

The working and middle class composition of the PSU student body is characterized by father's education ( $63.8 \%$ some college), mother's education ( $57.6 \%$ some college), father's occupation ( $55 \%$ white collar), parental family income $(39.6 \%$ over $\$ 25,000)$ and personal income $(22.5 \%$ over $\$ 7,000)$.

The vast majority of PSU respondents had passing to superior grades in high school $(86.6 \%)$ and appeared to be doing as well in college $(88.3 \%)$. While 76.8 percent of these respondents aspired to a bachelor's degree, only $50 \%$ actually aspired to eventually pursue graduate education.

About half ( $52.3 \%)$ of the students were of the conventional 18-21 age group. Nearly half of the remainder were 26 or older. Males and females were almost equally represented ( $49.4 \%$ male).

The lack of a campus enviroment is characterized by the fact that only 3.8 percent of the students responding actually lived on campus and only 11.7 percent 1 ived on or near campus. A large proportion of the PSU respondents lived with their parents $(41.9 \%)$. This lack of campus atmosphere tends to translate into a low proportion of students who have campus affiliations such as extra-curricular activities, sports, clubs (28.1\%). It also should be noted that only $42 \%$ of PSU respondents stated that most or all of their friends were students. 


\section{Reed College}

Reed College is one of the West Coast's few private Ivy League type, prestigious, liberal arts colleges. It has been in existence for nearly this entire century. Its walls are actually covered with ivy. Reed has quite a reputation in regard to academic rigor. Nearly a third of Reed's students are from the Northeast. Only a very few students are from the south. Nearly half are from the West Coast. The tuition for Reed College is quite high. It is many times greater than for public colleges and universities in 0regon.

Most of the Reed respondents ( $84.5 \%)$ received some parental economic support. This was the dominant source of support. Some students also received some support from personal savings ( $46 \%$ ) and employment $(50.4 \%)$. Over two-thirds $(67.2 \%)$ of this employment was on campus.

The upper middle class composition of the Reed College student body is characterized by father's education ( $88.8 \%$ some college), mother's education ( $87.7 \%$ some college), father's occupation $(81.8 \%$ white collar), parental family income $(58.2 \%$ over $\$ 25,000)$ and personal income $(4 \%$ over $\$ 7,000)$.

A very large proportion of the Reed respondents had passing to superior grades $(96.2 \%)$ in high school and appeared to be doing nearly as well in college $(90.4 \%)$. The relatively high aspirations of Reed College students was expressed by 77.7 percent who expect to achieve their bachelor's degree and 82 percent who aspired to eventually attend a graduate school.

Most Reed students are of conventional college age, 18-21 years (73.2\%). Nearly all of the remaining Reed students in this research 
were 21-25 years old. There were practically no students 26 years or older who were full-time students at Reed. Males tended to slightly outnumber females in their enrollment at Reed ( $56.3 \%$ male).

Reed does appear to have a campus environment. This is characterized by 40.8 percent of the respondents 1 iving on campus. The inclusion of those living near campus raises this proportion to 75.2 percent. Only 6.4 percent of the Reed respondents lived with their parents. This campus atmosphere tends to translate into a relatively high proportion of students who have campus affiliations ( $65.1 \%)$. Many of these students have more than one affiliation. Reed students also tended to report that most or all of their friends were students $(83.2 \%)$.

\section{Summary of Institution Descriptions}

These two college enviroments were at least partially selected for this research because of these differences in student composition and general campus life-style. PSU is a non-campus environment predominantly occupied by students from primarily working and middle class backgrounds. Reed has a campus enviroment permeated by an Ivy League mystique and a predominantly upper middle class student body. If there are some variables which prove to be significant in explaining attendance patterns that transcend specific school enviroments and student backgrounds, then there might certainly be grounds to generalize these conclusions to most or all students, regardless of school or other student advantages or disadvantages. If not, then great care must be taken to avoid making such generalizations regarding schools of radically different make-up. Clark and Trow (1966) have suggested that 
significant differences in campus and student enviroments regarding values and goals do exist. Such differences may translate into differing attendance patterns.

THE RELEVANCE OF THE MODELS

The following discussions will present first the thematically ordered qualitative responses of nonreturning students regarding why they left school. The path analytic tests of the relative efficacy of the social class and involvement propositions will then be discussed in the analysis of each school.

\section{Portland State University (PSU)}

While responses to why students had left school were varied, certain patterns became apparent when responses were grouped by their thematic similarity. Nine categories of responses are presented in Table III. Nearly all of the nonreturning students at PSU $(96.7 \%)$ responded to this question. A few students gave multiple responses.

\section{TABLE III}

\section{STUDENTS SAY WHY THEY LEAVE PSU}

\section{Reason}

Work, time or money related Transfer

Family, personal problems

Response to PSU

Personal ambivalence

Work opportunity in field

Travel/recreation

Moved

Reserve military obligation

Total
Number of

Responses

39

16

15

13

6

4

4

1

1

99
Percentage of Total Responses

$39.4 \%$

$16.2 \%$

$15.2 \%$

$13.1 \%$

$6.1 \%$

$4.0 \%$

$4.0 \%$

$1.0 \%$

$1.0 \%$

$100.0 \%$ 
The dominant reasons that students gave for leaving PSU were work, time or money related: "lack of money" ( $n=13)$; "to find work" $(n=17)$; "did not qualify for financial aid" ( $n=4)$; and "work/school conflict" $(n=5)$. Nearly 40 percent of the responses fell into this somewhat economic category, more than twice as many as any other category. This seems to highlight the fact that PSU is a working-student university and the importance of adequate economic resources to support continued attendance. The prominence of these concerns at PSU appear to provide some credence to the social class arguments, especially regarding access to economic resources.

The second and third most often reported categories were transfers (16.2\%) and family and personal problems (15.2\%). The latter category has some applicability to the involvement propositions, primarily to note that involvements external to the academic environment are often factors in leaving school. "Getting married" ( $n=4)$, "family obligations" ( $n=7)$ and "injury" or "illness" to self or intimate others $(n=4)$ are reasons students give for leaving PSU in this category of responses .

The final major category of responses make reference to problems students had with PSU which influenced them to leave school. At the top of the list was a dissatisfaction with their department $(n=5)$. These students reported a boredom or disillusionment with their major. Others thought that PSU had a poor social and study atmosphere $(n=5)$, that they were mistreated by the administration $(n=2)$ and that PSU was just too far to commute $(n=1)$. This category tends also to be somewhat supportive of the involvement propositions regarding intensity of 
program interest and general involvement in the student academic environment.

Analysis of the positive and negative evaluations of the continuing and nonreturning students regarding their experiences at PSU has been reported in another source (Daugherty 1978). Very few differences in such evaluations were found in a comparison of the responses of continuing and nonreturning students. None of these differences were pertinent to the questions to be discussed in this thesis.

This presentation of the qualitative responses of nonreturning students to the question of why they left PSU certainly appears to provide strong support to the social class arguments regarding attrition. Some support is also provided to many of the involvement propositions. It is the next stage of the analysis which provides the real test as to the relative efficacy of the involvement and social class models and the validity of the propositions which comprise these models at PSU.

The large number of variables and confusion of paths presented in Figure 1 are reduced, through factor analysis, to a more workable set of propositions that simplify the paths of causation. Table IV presents the varimax rotated factor matrix for the six social class variables. The number of social class variables is, thus, reduced to three factors represented by father's education, father's occupation and employment. Father's education, father's occupation and employment absorb mother's education, family income and personal income respectively. 
TABLE IV

VARIMAX ROTATED FACTOR MATRIX OF SOCIAL CLASS VARIABLES AT PSU

Variables

Father's education Mother's education

Father's occupation

Family income

Personal income

Employment

Eigenvalue

Explained variance
Factor 1 Factor 2 Factor 3

$$
.662
$$

.568

.108

.091

$-.088$

$-.019$

1.129

$63.6 \%$

$$
.314
$$

.034

.614

.402

$-.088$

.029

.423

$23.8 \%$
.065

.058

.240

.014

$-.276$

.444

.224

$12.6 \%$

The same procedure is applied to the eight involvement model variables. This varimax rotated factor matrix is presented in Table $v$. The eight involvement model variables are reduced to five factors represented by college GPA, campus work, program interest, residence and affiliations. College GPA, affiliations and campus work absorb high school GPA, student friends and academic relatedness of work respectively.

The relative efficacy of these two models can readily be established by a comparison of the variance explained by the social class and involvement variables. This is accomplished by a simple comparison of the $\mathrm{R}^{2}$ of these two sets of variables on attendance pattern. The $\mathrm{R}^{2} \mathrm{~s}$ are derived from multiple regressions of the respective variables on the dependent variable, attendance pattern. Independent of each other, neither set of variables explain very much of the variance. The three social class variables have an $R^{2}$ of .017 on attendance pattern. These variables explain less than 2 percent of the variance of attendance pattern. The five involvement variables have an $\mathrm{R}^{2}$ of .025 on attendance pattern. These variables explain only 2.5 


\section{TABLE V}

VARIMAX ROTATED FACTOR MATRIX OF INVOLVEMENT VARIABLES AT PSU

Variables

College GPA

High School GPA

Student friends

Campus Work

Academic related work

Program interest

Residence

Affiliations

Eigenvalue

Explained

variance
Factor 1 .228

$-.065$

$-.091$

.034

$-.054$

.700

.030

.191

.771

$33.9 \%$

\section{Fact or}

.551

.454

.099

$-.047$

.058

.068

.039

$-.006$

.470

$20.7 \%$

\section{Factor 3}

.048
.048
.377
-.046

.001

.071

$-.025$

.542

.410

$18.1 \%$

\section{Fact or 5}

.118

$-.059$

$-.182$

.337

.051

.018

.298

$-.050$

.054

.075

.241

.379

$16.7 \%$

$10.6 \%$

percent of attendance pattern. The combined effect of all eight variables does increase the $R^{2}$ on attendance pattern to .042 . But still, only slightly more than 4 percent of variance explained is very low, to say the least. The efficacy of either model, or both models combined, is very much in question. None go far at all in explaining the variance of attendance pattern at PSU.

Even though the actual implications of these mode1s appear inconsequential, the propositions presented in Figure 1 are still amenable to test by path analysis. It is how the variance is explained, rather than the amount of variance explained that is the focus of this test. The eight variables derived from the two previous factor analyses are presented in Figure 2 in a fashion representative of the propositions articulated in Figure 1. It is proposed that living and working on campus help to build affiliations (and friendships) which increase interest in programs of study, improve grades and, therefore, 


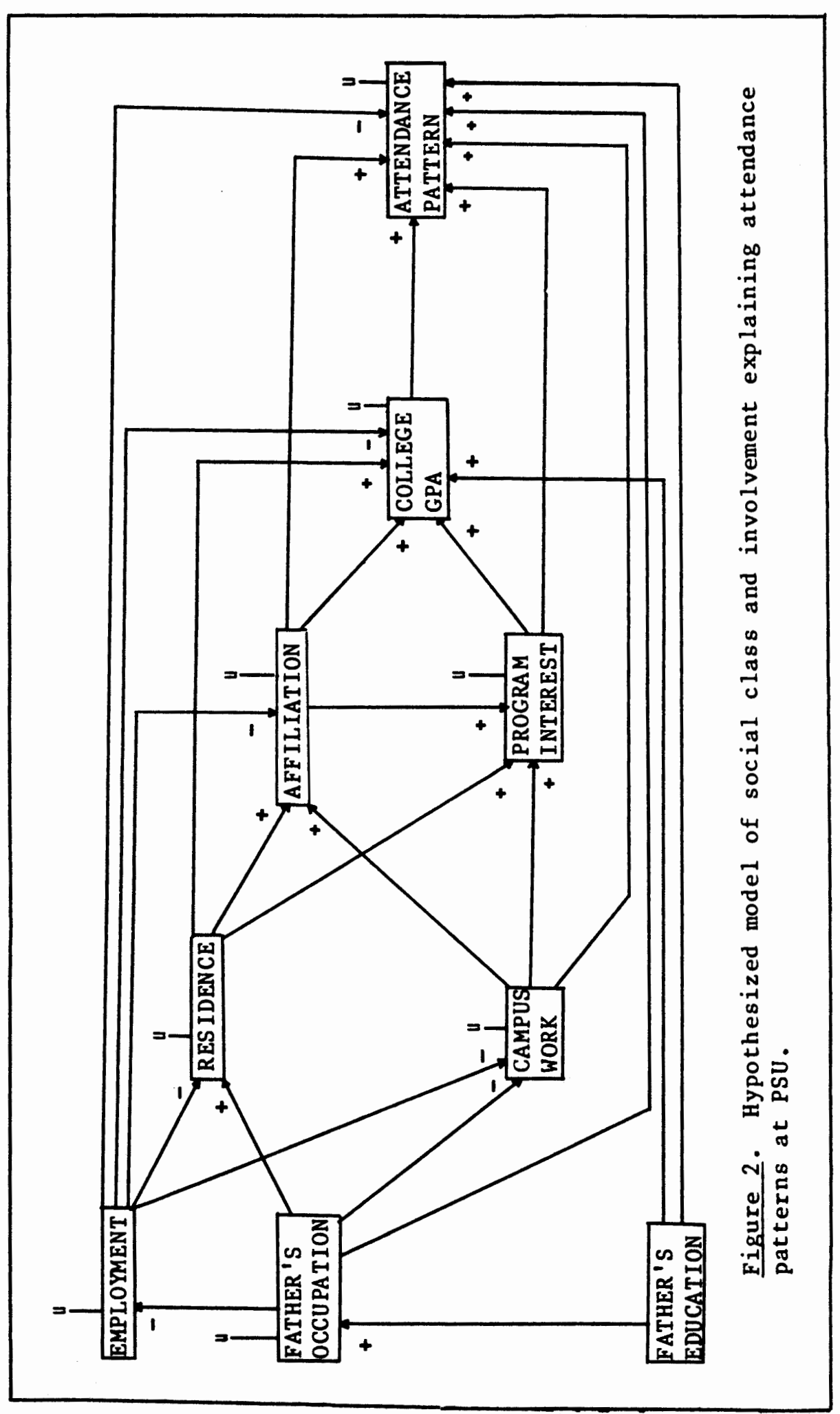


continuing student status. It is al so proposed that social class variables will have an impact on the involvement variables themselves, as well as more direct consequences for attendance pattern.

Figure 3 presents the actual model of social class and involvement variables in explaining attendance patterns. All paths with path coefficients less than .05 are deleted from the model. Non-hypothesized paths with path coefficients equal to or greater than .05 have been added.

The most obvious finding in regard to the propositions displayed in Figure 3 is that they are very inconclusive. No clear lines of causation appear to exist. The most powerful statement these propositions make is the high unexplained variance. The relationships expressed here are diffuse. Given the low criteria for deletion, these variables do hang together as would be expected from the literature, but with very low path coefficients. If .1 had been the criteria of deletion or inclusion, few relationships would remain. Clearly, this model appears inadequate to explain the stop outs' interruption of studies at PSU. Neither the involvement or social class variables go far in explaining the stop out. Yet, PSU students gave qualitative responses which inferred that at least the social class variables may have some affect.

The subjective concern over money, time and work does not appear to be reflected in the objective measures of social class. There may be no necessary correlation between subjective and objective evaluations of need. On the other hand, something may have caused many of the stop outs to re-evaluate the imediate priority of these concerns or of continuing college relative to these concerns that has not so affected 


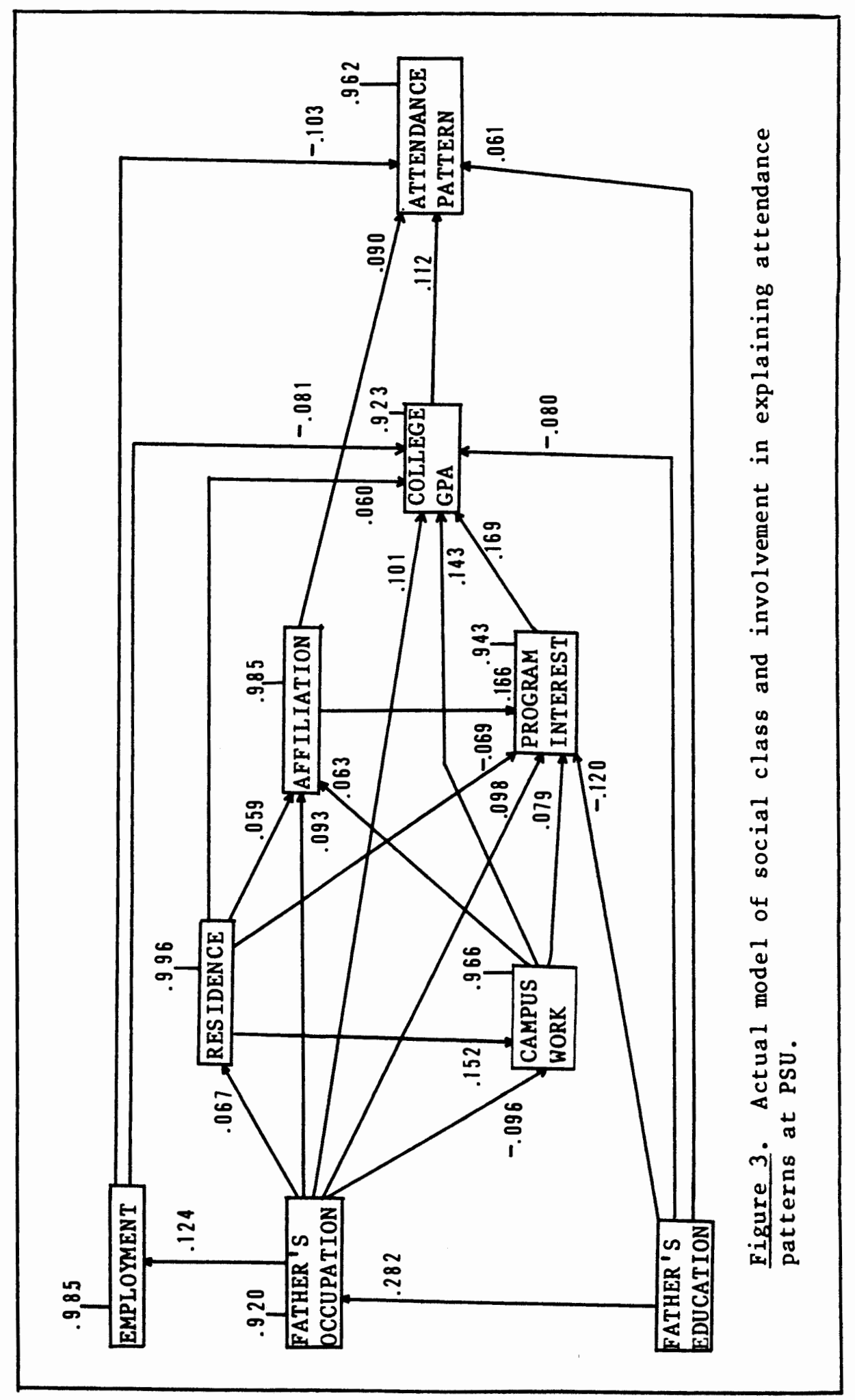


the continuing students. This latter point appears to be substantiated at PSU by an interpretation of data to be discussed as an alternative explanation near the close of this chapter.

This test of social class and involvement propostions has provided little to clarify the discussion of stop outs or attrition in general. These two explanatory models appear not to be substantiated at PSU. Let us apply the test to Reed College before drawing any final conclusions as to their general applicability.

\section{Reed College}

As with PSU, qualitative data was gathered at Reed regarding nonreturning student self-perceptions of why they left school. These varied responses were also categorized according to thematic similarities. Eight categories were so derived and are displayed in Table VI. Most of the Reed nonreturning students responded to this question $(91.7 \%)$ and a few students gave multiple responses.

\section{TABLE VI}

\section{STUDENTS SAY WHY THEY LEAVE REED}

\section{$\underline{\text { Reason }}$}

Reaction to Reed

Change of career goals

Pressure/anguish

Transfer to another school

Family iliness

Financial

Vacation/break from studies

Career related job opportunity

Tota 1
Number of Percentage of

Responses Total Responses

11

8

7

4

3

3

3

1

40
$27.5 \%$

$20.0 \%$

$17.5 \%$

$10.0 \%$

$7.5 \%$

$7.5 \%$

$7.5 \%$

$2.5 \%$

$100.0 \%$ 
The most reported reasons for leaving Reed were primarily in reference to the general atmosphere. The college was referred to as "too liberal" or "wild and radical" ( $n=3)$, "close" and confining ( $n=2)$, and "unrealistic" $(n=1)$. A few students felt that the enviroment made them "lonely", "unhappy", or "bored" $(n=3)$. Departments were perceived as "inadequate" $(n=2)$. Only 25.7 percent of the responses were accounted for by this category, but still more than any other grouping.

The second greatest reason for leaving Reed was a change in academic and career orientation, accounting for 20 percent of the responses. A few students came to the conclusion that academics were just not for them $(n=3)$. Others had made rather radical changes in their field of study $(n=5)$. This latter group is likely to be only taking a break to re-evaluate their situation or may intend continuing their new interest at another school.

The third major category, pressure/anguish, accounts for 17.5 percent of the responses. The academic and social pressures of the school were perceived as creating mental anguish. Students quite often found themselves "anxious" or "depressed" $(n=6)$. One student felt there was just "too much studying" $(n=1)$.

Nearly two-thirds $(65.0 \%)$ of the responses are accounted for by the above three groupings. Very few of these responses relate much to either the social class or involvement propositions. Only 7.5 percent of the responses addressed financial concerns. The evaluations of nonreturning and continuing students regarding their college experiences did not really differ significantly. Even less relevance of the models may be expected at Reed College.

The confusion of paths of causation and large number of variables 
is again made more parsimonious by factor analysis. New factor analyses are required here because the factor loadings are expected to differ from school to school because of unique variations of school environment, heritage and student body, especially with two schools as distinctly different as Reed and PSU. Clark and Trow (1966) have documented the existence of such differences within and between schools. It is suspected that such varied enviroments within and between schools will have a differential influence on respective student attendance patterns.

Table VII presents the varimax rotated factor matrix for the six social class variables. The social class variables are reduced to three factors represented by mother's education, family income and employment. These factors are somewhat different from those at PSU. Mother's education appears to absorb father's education and occupation and employment incorporates personal income.

This procedure is repeated for the eight involvement variables. The varimax rotated factor matrix is presented in Table VIII. These eight variables are reduced to four factors represented by student friends, college GPA, affiliations and high school GPA.

The $\mathrm{R}^{2} \mathrm{~s}$ for these involvement and social class variables on attendance pattern were calculated. The $\mathrm{R}^{2}$ of the social class variables on attendance patterns was .006 . The $R^{2}$ of the involvement variables on attendance pattern was .006. These are very low. Neither set of variables explains even one percent of the variance of attendance pattern independent of the other. Their combined $\mathrm{R}^{2}$ on attendance pattern is only .014, slightly over one percent of the variance. 
TABLE VII

VARIMAX ROTATED FACTOR MATRIX OF SOCIAL CLASS VARIABLES AT REED

Variables

Father's education

Mother's education

Father's occupation

Family income

Personal income

Employment

Eigenvalue

Explained variance
Factor 1 Factor 2 Factor 3

$\begin{array}{rrr}.763 & .120 & -.014 \\ .767 & -.050 & -.348 \\ .513 & .277 & -.004 \\ .262 & .693 & .217 \\ -.050 & .009 & .247 \\ .016 & -.429 & .308 \\ 1.688 & .646 & .255 \\ 65.2 \% & 24.9 \% & 9.9 \%\end{array}$

TABLE VIII

VARIMAX ROTATED FACTOR MATRIX OF INVOLVEMENT VARIABLES AT REED

Variables

College GPA

High School GPA

Student friends

Campus Work

Academic related

work

Program interest

Residence

Affiliations

Eigenvalue

Explained

variance
Factor 1 Fact or 2 Factor 3 Factor 4

$\begin{array}{rrrr}.228 & .551 & .048 & -.159 \\ -.065 & .454 & .048 & .169 \\ -.091 & .099 & .377 & .051 \\ .034 & -.047 & -.046 & .018 \\ -.054 & .058 & .001 & .015 \\ .700 & .068 & .071 & .039 \\ .030 & .039 & -.025 & .006 \\ .191 & -.006 & .542 & -.083 \\ .771 & .470 & .410 & .379 \\ 33.9 \% & 20.7 \% & 18.1 \% & 16.7 \%\end{array}$

This is so low as to be almost meaningless. Yet, as before, the focus of the test is to address how the variance is explained rather than the amount of variance explained. The seven variables derived from the previous two factor analyses are presented in Figure 4. This model proposes that school affiliations lead to student friendships which help to build comitments to a student lifestyle and better grades, hence, continuing student status. High school performance is al so a factor 


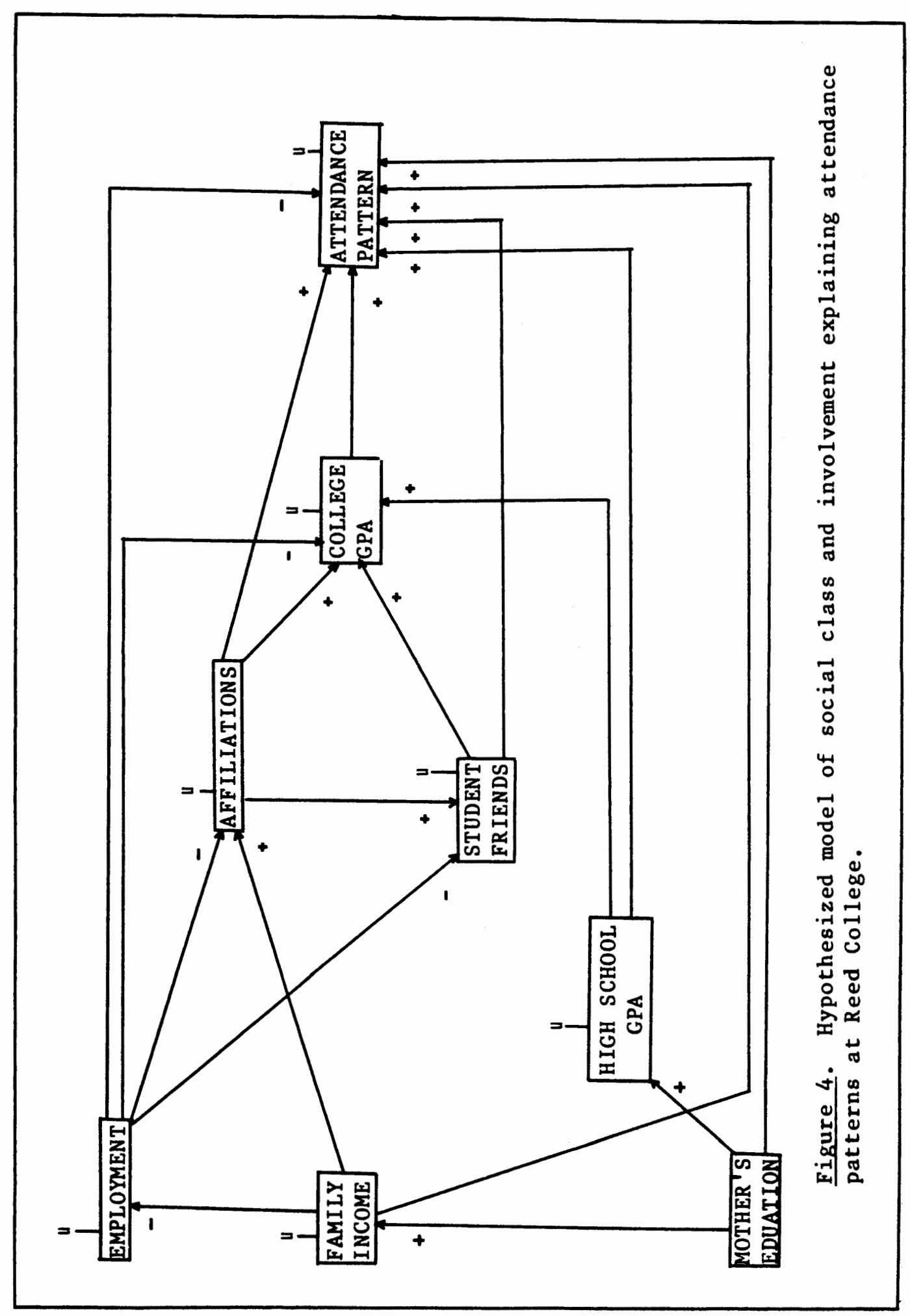


here translating previous skills into better college grades. Social class variables impinge on these other variables at several points. Working is expected to interfere with such affiliations, friendships, college GPA and continuing student status. The other social class variables (mother's education and family income) will also affect these involvement variables, as well as attendance pattern.

Figure 5 presents the actual model of social class and involvement variables in explaining attendance patterns. All paths with path coefficients less than .05 are deleted from the model. Non-hypothesized paths with path coefficients equal to or greater than .05 have been included.

As with the path analysis presented for PSU, the most striking point is the unexplained variance at all the causal points of the model. The model appears to be even less applicable to explaining stop outs at Reed College than it is at PSU. No clear 1 ines of causation can be inferred from this model. Very few of the variables have any direct affect on attendance patterns.

The propositions that were suggested in the literature find very little support in these path analytic tests for their application to the stop out student. It may even be questioned whether they are applicable to attrition in general, or the drop out in particular. This latter point can only be addressed by an application of these tests to the drop out students, if they could be persuaded to participate in the study. One more approach to explaining stop outs can be addressed in this thesis: the problem of career planning. 


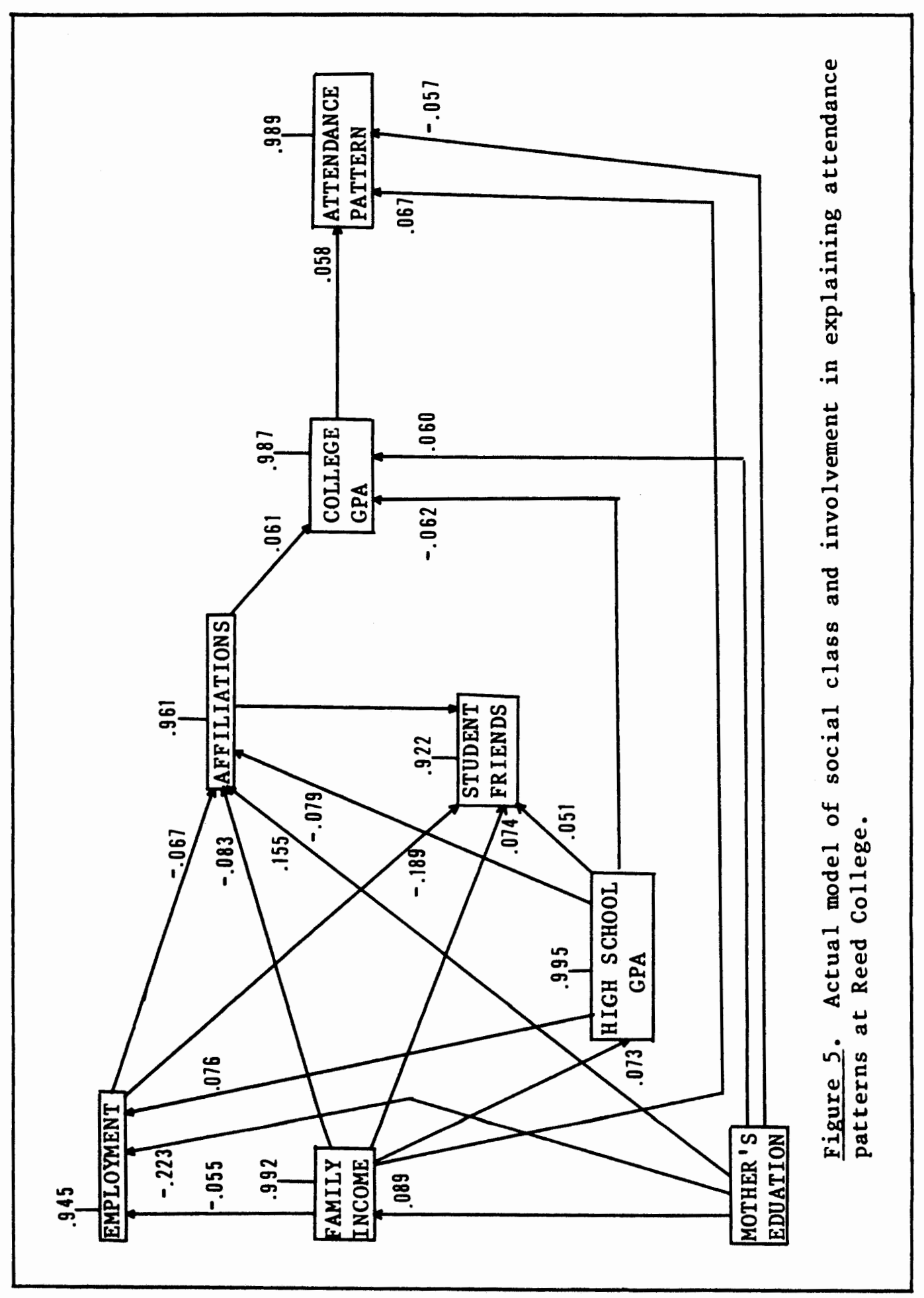


CAREER PLANNING: AN ALTERNATIVE EXPLANATION

As discussed earlier, Stinchcombe (1964) and Hillery (1978; 1981), earlier, have suggested that a mismatch may exist between student interests and aspirations and the lack of availability of positions in their field upon graduation. It was suggested that when discovering this many students may leave school to re-evaluate their future course of action. Some of them will return. Some will not. The remainder of this chapter will examine this alternative explanation.

To address this explanation several facts should first be established. Attrition of stop outs must be demonstrated to vary by area of study, division of study in this case. Chances of employment upon graduation must also vary, or at least be perceived by students as varying between divisions of study. Finally, it must be demonstrated that perceived employment opportunities affect attendance patterns within divisions of study.

Table IX presents the attrition of stop outs at both PSU and Reed College for the three comparable divisions of study. This table does demonstrate consistent differences in attendance pattern by major at both schools. Science majors have the lowest attrition, followed by social science and arts \& letters majors, in that order. Reed demonstrates a far lower attrition in these three divisions than PSU, though still consistent in the order.

Table $X$ demonstrates that perceptions of employment chances upon graduation also vary by major and these are consistent in order at both schools. This is, in fact, the same order presented in Table IX. Science majors were the most likely to perceive their employment chances 
TABLE IX

ATTRITION OF STOP OUT STUDENTS BY MAJOR AT PSU AND REED COLLEGE

Maior

Science

Social science

Arts \& Letters
PSU Attrition

$10.4 \%$

$14.5 \%$

$22.6 \%$
Reed Attrition

$1.1 \%$

$5.4 \%$

$13.6 \%$

as good, followed by social science and arts \& letters majors. It should be noted that these perceptions are probably quite accurate reflections of reality vis a vis relative job opportunities for these majors. These perceptions are very similar in magnitude at the two schools.

\section{TABLE $X$}

THE PROPORTION OF STUDENTS AT PSU AND REED COLLEGE WHO PERCEIVE THEIR CHANCES OF

EMPLOYMENT AS GOOD

$\begin{array}{lcl}\text { Major } & \text { PSU } & \text { Reed } \\ \text { Science } & 58.9 \% & 52.1 \% \\ \text { Social Science } & 37.7 \% & 35.1 \% \\ \text { Arts \& Letters } & 21.8 \% & 18.3 \%\end{array}$

Tests were made of effect of the perceived chances of employment on attendance patterns at PSU and Reed, controlling for major. Only one relationship at either school was found to be significant, the science major at PSU. This was the most numerous category $(n=95)$. This relationship is displayed in Table XI. A rather moderate to high correlation exists here. All but one of the remaining, but not significant relationships at PSU ( 7 in number) have correlations in the appropriate direction. These correlations of the perceived chances of employment after graduation on attendance patterns are presented by 
TABLE XI

THE EFFECT OF THE PERCEIVED CHANCES OF EMPLOYMENT ON ATTENDANCE PATTERNS OF PSU SCIENCE MAJORS

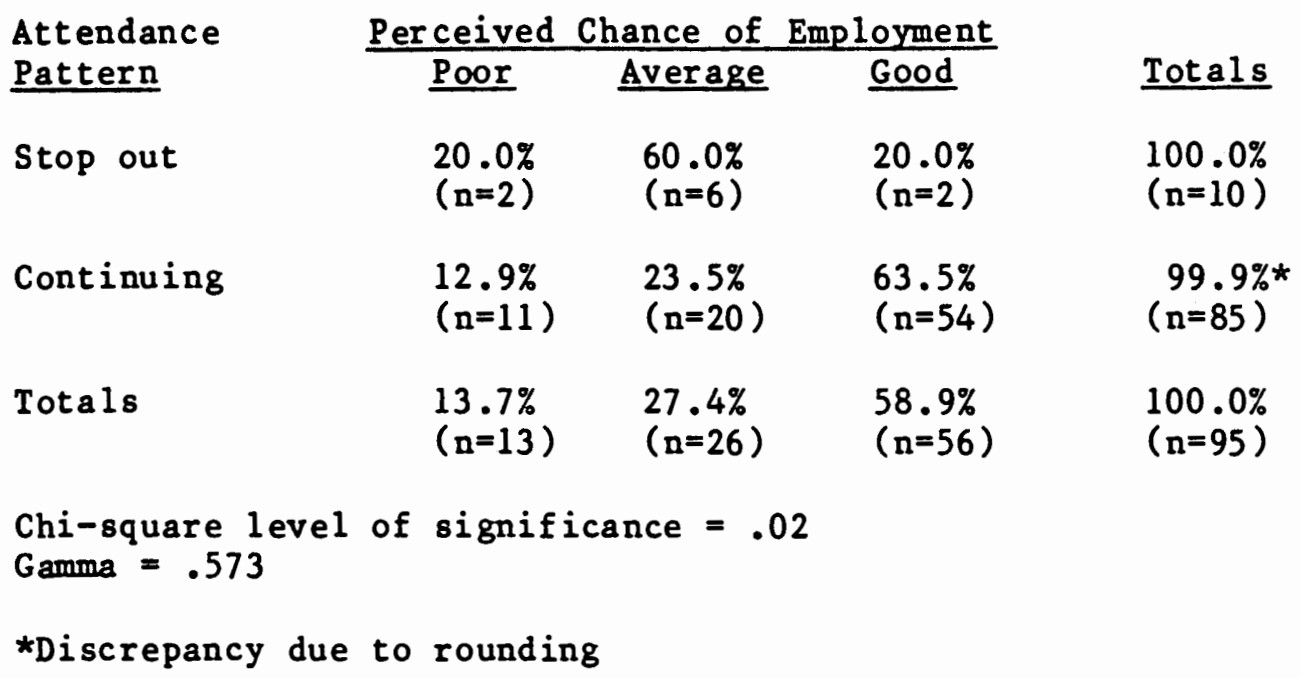

major for both PSU and Reed College in Table XII. The magnitude of these correlations at PSU also seem to be somewhat consistent. The major exceptions at PSU are general studies and social science. The former has the only negative correlation. This may reflect those students who wish to stay in college, but do not know what they want to do. They, thus, select a general studies degree enabling them to continue toward a degree of some sort, regardless of employment chances. Potential stop outs may utilize this major to continue their education while re-evaluating their future course of action in planning a career. Other students may stop out to make such a re-evaluation. The low correlation for social science majors may reflect the mixed motives students have in pursuing this interest. They have involved themselves in social science disciplines for more than just a job. Many of these students appear willing to continue attending PSU as social science majors despite a perceived poor chance of employment upon graduation. 
TABLE XII

GAMMA CORRELATIONS OF THE PERCEIVED CHANCES OF

EMPLOYMENT ON THE ATTENDANCE PATTERNS OF

PSU AND REED STUDENTS BY MAJOR

Major

Undeclared

General Studies

Busines 8

Education

Heal th \& PE

Arts \& Ietters

Science

Social science
Gamma Correlations

$\underline{\text { PSU }} \underline{\text { Reed }}$

$\begin{array}{rr}.500 & \text { No stop outs } \\ -.800 & \text { N/A } \\ .154 & \text { N/A } \\ .333 & \text { N/A } \\ .500 & \text { N/A } \\ .249 & .097 \\ .573 & -1.000 \\ .037 & -.674\end{array}$

None of the relationships for Reed College depicted in Table XII were found to be significant. Two of these majors had rather high negative correlations. Perhaps the chances of employment, given a specific degree, are not relevant to their decisions to continue their education at Reed. Reed College students may not be working toward a career in the same sense as PSU students. A college education may have some other function for Reed students, hence, their reluctance to stop out, regardless of the chances for employment in their major upon graduation.

Clark and Trow (1966), cited earlier, have defined at least four distinct student subcultures: collegiate, academic, nonconformist and vocational. These student subcultures are depicted in Table XIII as the product of the relationship between their involvement with ideas and their identification with their college. The authors recognize most colleges may have a mix involving all four types. They al so note that many colleges may be dominated by a particular student subculture which both creates and sustains a certain ethos. The collegiate subculture is 
TABLE XIII

TYPES OF ORIENTATIONS OF FOUR MOST DISTINGUISHABLE

STUDENT SUBCULTURES

\begin{tabular}{ccc|c|} 
& \multicolumn{2}{c}{$\begin{array}{c}\text { Involvement with Ideas } \\
\text { Iuch }\end{array}$} & \multicolumn{1}{c}{ Little } \\
\cline { 3 - 4 } Identification With & Much & Academic & Collegiate \\
\cline { 3 - 4 } Their College & Little & Nonconformist & Vocational \\
\cline { 3 - 4 } & &
\end{tabular}

Clark, Burton R. and Martin Trow. "The Organizational Context." In College Peer Groups. Ed. Theodore M. Newcomb and Everett K. Wilson. Chicago: Aldine Publishing Co., 1966, p. 24.

characterized by a relatively low involvement with ideas and a high identification with their college. College is perceived somewhat as a party and is expressed through a "play" mentality. The academic subculture is characterized by both a high involvement with ideas and high identification with their college. Students have some rapport with their instructors and take pride in the academic rigor their course of study requires. The nonconformist subculture tends to have a low identification with their college, but maintains a high involvement with ideas. The particular college is merely a forum for their development, one place among many where these students may express their varied concerns. Finally, the vocational subculture is characterized by both little identification with their college and little involvement with ideas. College is a place to go to get credentials to enter the job market. College, in this latter case, tends to be a means to an end. Attrition, a decision to stop out in this case, appears to be the product of a rather pragmatic conclusion on the part of students at PSU. These students tend to be interested in developing a career through 
their college education. Students at PSU seem to be vocational in their orientation to a college education. An education is the means toward the development of a career upon graduation. If a degree in the student's major is perceived to be unlikely to get the student a job, then he/she seems to be taking a break to re-evaluate their present course of action. Reed College students are, apparently, not as career oriented regarding their college education as PSU students appear to be. It is suggested here that their intent may be more academic and nonconformist than vocational.

Perhaps it is to the above points that the qualitative responses discussed earlier are providing support. The nonreturning students at PSU expressed a clear concern (39.4\%) for work, time and money related factors in their decision to not return to PSU. These statements, suggesting low social class and inadequate support systems as a reason for leaving school, were not substantiated in the tests of the social class and involvement hypotheses. While not included in the initial intent of this thesis, it is suggested that these qualitative responses are not addressing social class directly, but are expressions of a re-evaluation of the merits of an education in their area of study. The concern for finances as an explanation of this break in attendance does not appear substantiated by objective measures of social class. It is suggested these concerns may have a subjective value and are affected by the relative merit of continuing in an apparently dead-end career. It becomes difficult to defer gratification when the future for employment is a losing proposition. Students confronting this dilemma appear to be making a relatively rational choice to disengage from college with the intent of returning, but after some re-evaluation of career choices. 
This would further suggest the vocational character (a means to employment) of a college education as a career step for PSU students. These students appear to be re-evaluating the relative worth of a college education and, for that matter, appear to be re-evaluating the relative worth of noneducational options as well. The very lack of such concerns and relationships at Reed reflect its particular atmosphere. It is suggested that this lack of career concern may reflect an academic or nonconformist function of an education at Reed College. The Reed nonreturning student qualitative responses certainly demonstrated a reaction to Reed $(27.5 \%$ ) and changes in career goals (20\%) as reasons for stopping out from Reed. The changes in plans regarding continuing at Reed College appear quite unrelated to the perception of employment chances. 
CHAPTER VI

\section{SUMMARY AND CONCLUSIONS}

This is an exploratory research of stop outs, comprising a sizable proportion of attrition from schools of higher education. The focus has been on explaining attendance pattern which was comprised of two categories: the stop out and the continuing student.

Two explanatory models, each purporting to explain attrition in a theoretical fashion, were tested at two significantly different institutions of higher education: Portland State University and Reed College. The involvement hypothesis suggests that if the students are involved in the academic environment, then they are far more likely to continue in their studies toward certification or degree than if not involved. Such involvement is indicated by residence, academic friendships, campus affiliations, program interest, academic performance, college GPA, campus work and academic relatedness of work. The social class model stressed that social class factors (family income, employment, father's occupation, parents' education and personal income) acted as a resource base which would help or hinder a student depending upon whether he or she had high or low social class ranking on these variables. These variables were reduced to a workable model with factor analysis and tested by path analysis. Neither explanatory model was found to explain attrition at either Reed College or PSU. Even when combined, the variables explained little variance. This is particularly 
surprising at PSU where qualitative responses suggested a concern for time, money or finding work as reasons for taking a temporary break from school. It is suggested that these reasons reflect the need to re-evaluate the relative worth of a college education, given specific majors, in finding career employment upon graduation. The relationship between perceived chances of employment and major was significant at both PSU and Reed College. A rather pragmatic evaluation of employment possibilities varied by major. These evaluations were realistic ones. Controlling for major, the effect of the perceived chances of employment on attendance pattern was found to be significant in the case of science majors at PSU. If the sample sizes were larger, this relationship may well have appeared significant in other majors as well. Rather than social class or involvements explaining attrition, pragmatic choices involving career goals appear to play an important role at some schools. PSU is one. Students at PSU apparently are vocationally oriented regarding college attendance and this does not appear to be directly related to social class. A college degree is perceived as an important factor in establishing a career upon graduation. Students at PSU appear to be taking a break to re-evaluate their options when the chances of employment are perceived as not being good in their area of study.

No such relationship is perceived to be operating at Reed College. The orientations of Reed College students appears to be far less vocational than those at PSU. This difference suggests that the school itself may be an important variable explaining attrition. Each school has a different campus enviroment, partially a product of the specific heritage of the school, the composition of the student body and other variables. This enviromental influence is likely to be reflected in 
different student goals and aspirations at different schools. The schools themselves must be considered as an important variable in explaining the variation of attrition.

The analysis of career goals and perceived employment chances upon graduation suggests that students in specific majors may be making pragmatic decisions to continue or discontinue their college education based on their perceived chances of employment upon receiving a degree. If employment chances are perceived as poor, we are left with the question of why this major was initially selected by the student. Employment upon receiving a degree might not be an issue for some students. Some students may be working in a subject area for intrinsic values rather than career goals. Others may have relatively wealthy families or access to resources that enable them to work in any area without the necessity for developing career goals. A final possible explanation of the mismatch of student major and career goals may be poor career counseling. Perhaps students are being provided with inadequate counseling in regard to their selection of major and long-term career goals. This is presented as a potential explanation for this phenomenon and is not the focus of this particular research. The problem of the mismatch between career goals and employment chances is partially beyond the school's sphere of control, primarily because colleges and universities have little direct influence on the job market. The school, however, must be somewhat attentive to this job market. It is reprehensible for some schools to be preparing students for dead-end careers or extended unemployment. Counselors and advisors within the colleges and universities need to be cognizant of potential job opportunities upon graduation in the various majors. One might 
argue that this is often intended as one of their functions in a university such as PSU. It might al so be argued from evidence presented in this thesis that they may not be fulfilling this function very adequately. Colleges should make an attempt to meet the needs and demands of their respective clientele, their students, and this involves career counseling at a university such as PSU.

\section{IMPLICATIONS FOR THEORY CONSTRUCTION}

The failure of the structural variables (measures of social class and involvements) to explain stop outs has suggested the need to develop an alternative focus to provide such an understanding. The alternative may be available through a somewhat different methodological and theoretical approach. The problem of career counseling demonstrates the foundations for the construction of such an alternative. The problem of a mismatch between career aspirations and the likelihood of achieving such employment upon graduation at PSU suggests the importance of considering student goals and the meaningfulness of a higher education for such students in attaining these goals. Rather than merely asking students why they are leaving school, it may be equally important to know why they are attending college to begin with. This approach requires that students be perceived as somewhat purposive beings. A college education is meaningful for the student to the extent it is perceived as enabling the realization of such purpose(s). This is not to imply that students are unidirectional or narrow in purpose. College may be only one contingency among many for achieving such goals. Many students are also likely to have mixed motives or purposes in attending college. It is the answer to the question regarding purpose and meaning 
that future research needs to address. Rather than merely a focus on structural variables, the application and development of theoretical knowledge must delineate the meaning-frameworks of students and how these may change as a result of changes in perception of goals and the possibilities of the realization of these goals given a present course of action.

Such a refocusing may require a perspective in the symbolic interactionist orientation. This perspective focuses explanation on the importance of the definition of the situation by participants in it as they choose among various role contingencies. The meanings and purposes that participants impute to situations are the basis for that definition and provide the foundations for the choice among various options they may perceive. The student is, thus, acting as a conscious being with purposive intent. This, of course, need not exclude structural variables from the analysis. The role of structural variables may still act as variables with indirect effects shaping options among contingencies as well as among goals. Such a reorientation of analysis requires a focus upon why students are going to college and what factors, both internal and external to the college situation, lead students to re-evaluate their courses of action. Such a focus requires the orientation to be somewhat open-ended, enabling student perceptions of the situation and the possibilities of realization of goals to be available as data. Both objective (the use of structural variables) and subjective (the use of student perceptions) forms of data must be utilized in such an effort. 
METHODOLOGICAL RECOMMENDATIONS

This research was exploratory. It was designed to test competing hypotheses and develop the foundations for further research regarding the explanation of attrition, particularly the attrition of stop outs. Future research in this area of attrition must address several of the methodological shortcomings of this research. Several such methodological recommendations can be made.

First, and foremost, is the call for a longitudinal research of attrition. A cohort of entering students should be followed through their progress toward achieving a degree. There should be both entrance and exit interviews and/or questionnaires of these students addressing their attendance patterns. In this fashion, the actual causation of their attrition can be better analyzed and understood rather than inferred or assumed as with the cross-sectional approach. An entire cohort of entering students at most colleges would also provide a large enough number of responses to make more complex techniques of control and analysis possible.

An analysis of attrition in general must include drop outs. Drop out responses must somehow be elicited. Perhaps, the use of economic incentives may encourage this group to respond to interviews and questionnaires. Such incentives may also bias response rates. The requirement of exit interviews may be a means of achieving this goal. The question of attrition cannot really be fully addressed without the inclusion of these drop outs.

If the previous two recommendations can be achieved, then a third recommendation is that this test of the involvement and social class 
explanations of attrition, with the inclusion of the more pragmatic option of career choices and perceptions of employment chances be repeated. These explanatory models may still have some relevance in explaining drop outs. This analysis should be repeated at a variety of different colleges and universities. Schools of higher education cannot be indiscriminantly pooled to discuss attrition. Each school, as this research suggests, may have characteristics unique to it and its student body that affect attendance patterns differently.

Finally, not only should students be asked why they are leaving college, but why they are going to college to begin with. Their perception of goal priorities and the changing possibilities of their realization can then be elicited. 
SOURCES CONSULTED

BOORS AND ARTICLES

Anderson, Edward "Chip". "A Retention Design Applied to an Equal

Opportunity Program." In Reducing the Dropout Rate. Ed. Lee

Noel. San Francisco: Jossey-Bass Inc., 1978, pp. 37-46.

Astin, Alexander. Preventing Students from Dropping Out. San

Francisco: Jossey-Bass, Inc., 1975.

- "College Dropouts: A National Profile". In Ace Research

Reports. Washington, D.C.: American Council of Education, 1972, PP. 1-71.

Blalock, Hubert M., Jr. An Introduction to Social Research. Englewood Cliffs, N.J.: Prentice-Hall, 1970.

- Social Statistics. New York: McGraw Hill, 1960.

Bowles, Samuel and Herbert Gintis. Schooling in Capitalist America. New York: Basic Books Inc., 1976.

Bronfrenbrenner, Urie. "Socialization and Social Class Through Time and Space." In Class, Status and Power. Ed. Bendix and Lipset. New York: The Free Press, 1966, pp. 362-377.

Campbe11, Donald T. and Julian C. Stanley. Experimental and Quasi-Experimental Designs for Research. Chicago: Rand McNally \& Co., 1963.

Clark, Burton R., Paul Heist, T. R. McConnel1, Martin A. Trow, and George Youge. Students and Colleges: Interaction and Change. Berkley, Calif.: Center for Research and Development in Higher Education, University of California, 1972.

and Martin Trow. "The Organizational Context." In College Peer Groups. Ed. Theodore M. Newcomb and Everett K. Wilson. Chicago: Aldine Publishing Co., 1966, pp. 17-70.

Cope, Robert G. "Why Students Stay, Why They Leave." In Reducing the Dropout Rate. Ed. Lee Noel. San Francisco: Jossey-Bass, Inc., 1978, pp. 1-11. 
Crockett, David S. "Academic Advising: A Cornerstone of Student Retention." In Reducing the Dropout Rate. Ed. Lee Noel. San Francisco: Jossey-Bass, Inc., 1978, pp. 29-35.

Davis, James A. Elementary Survey Analysis. Englewood Cliffs, N.J.: Prentice-Hall, 1971 .

Davis, Ringsley. "Reply." In Readings on Social Stratification. Ed. Melvin M. Tumin. Englewood Cliffs, N.J.: Prentice-Ha11, 1970, Pp. 386-391.

and Wilbert E. Moore. "Some Principles of Stratification." In Readings on Social Stratification. Ed. Melvin M. Tumin. Englewood Cliffs, N.J.: Prentice-Hall, 1970, pp. 368-377.

Fisher, James I. "College Student Retention from a Presidential Perspective." In Reducing the Dropout Rate. Ed. Lee Noel. San Francisco: Jossey-Bass, Inc., 1978, pp. 65-75.

Goode, William J. "Family and Mobility." In Class, Status and Power. Ed. Bendix and Lipset. New York: The Free Press, 1966, pp. $582-601$.

Havinghurst, Robert J. and Bernice L. Neugarten. Society and Education. Boston: Allyn \& Bacon, Inc., 1967.

Heise, David R. "Problems in Path Analysis and Causal Inference." In Sociological Methodology 1969. Ed. Edgar F. Borgatta. San Francisco: Jossey-Bass, Inc., 1968, PP. 3-37.

Hess, Robert D. and Virginia C. Shipman. "Early Experience and the Socialization of Cognitive Modes in Children." Child Development, 36, No. 4 (1965), 869-886.

Hillery, Milton C. "Maintaining Enrollments Through Career Planning." In Reducing the Dropout Rate. Ed. Lee Noel. San Francisco: Jossey-Bass, Inc., 1978, pp. 13-22.

Hoyt, Donald P. "A Retrospective and Prospective Examination of Retention-Attrition Research." In Reducing the Dropout Rate. Ed. Lee Noe1. San Francisco: Jossey-Bass, Inc., 1978, pp. 77-85.

Hul1, C. Hadlai and Norman H. Nie. SPSS Update: New Procedures and facilities for Releases 7 and 8 . New York: McGraw-Hill Book Company, 1979 .

Hyman, Herbert H. "The Value System of Different Classes." In Class, Status and Power. Ed. Bendix and Lipset. New York: The Free Pres s, 1966, pp. 488-499.

Jencks, Christoper and others. Inequality: A Reassessment of the Effect of Family and Schooling in America. New York: Basic Books, 1972 . 
Jose, James R. "Some Plain Talk on Retention by a College Dean." In Reducing the Dropout Rate. Ed. Lee Noel. San Francisco: Jossey-Bas s, Inc., 1978, pp. 57-63.

Rerlinger, Fred N. Foundations of Behavioral Research. New York: Holt, Rinehart and winston Inc., 1973.

and Elazar J. Pedhazur. Multiple Regression in Behavioral

Research. New York: Holt, Rinehart and Winston Inc., 1973.

Kuhn, Thomas S. The Structure of Scientific Revolutions. 2nd ed. Chicago: University of Chicago Press, 1970.

Land, Kenneth C. "Principles of Path Analysis." In Sociological Methodology 1969. Ed. Edgar F. Borgatta. San Francisco: Jossey-Bass, Inc., 1968, pp. 3-37.

Levine, Daniel U., Edna S. Mitchell and Robert J. Havinghurst. "Family Status, Type of High School and College Attendance." In Society and Education: A Book of Readings. Ed. R. J. Havinghurst, B. L.Neugarten and J. M. Folk. Boston: Allyn \& Bacon, Inc., 1971, pp. 8-98.

Michael, Donald N. On Learning to Plan and Planning to Learn. San Francisco: Jossey-Bass, Inc., 1973.

Miller, Myrna R. "Retaining Adults: New Educational Designs for a New Clientele." In Reducing the Dropout Rate. Ed. Lee Noel. San Francisco: Jossey-Bass, Inc., 1978, pp. 46-55.

Miller, S. M. and P. A. Roby. "Social Mobility, Equality and Education." Social Policy, 1, No. 1 (1970), 38-40.

Milner, M. The Illusion of Equality. San Francisco: Jossey-Bass, Inc., 1972 .

Moore, Wilbert E. "Comment." In Readings on Social Stratification. Ed. Melvin M. Tumin. Englewood Cliffs, N.J.: Prentice-Hall, 1970, pp. 391-392.

"But Some Are More Equal Than Others." In Readings on Social Stratification. Ed. Melvin M. Tumin. Englewood Cliffs, N.J.: Prentice-Hall, 1970, pp. 394-400.

"Rejoinder." In Readings on Social Stratifiction. Ed. Melvin M.Tumin. Englewood Cliffs, N.J.: Prentice-Hall, 1970, pp. 409-411.

Nie, Norman H., C. Hadlai Hull, Jean G. Jenkins, Karin Steinbrenner and Dale H. Bent. Statistical Package for the Social Sciences. San Francisco: McGraw-Hill, 1975. 
Noel, Lee. "First Steps in Starting a Campus Retention Program." In Reducing the Dropout Rate. Ed. Lee Noel. San Francisco: Jossey-Bas 8, Inc., 1978, pp. 87-98.

Onushkin, Victor G. Assisted by B. C. Sanyal and G. Bartagnon. Planning the Development of Universities - II. Paris: Unesco: International Institute for Educational Planning, 1973.

Ott, Linda S. "Admissions Management with the Focus on Retention." In Reducing the Dropout Rate. Ed. Lee Noel. San Francisco: Jossey-Bass, Inc., 1978, pp. 23-28.

Pantages, Timothy J. and Carol F. Creedon. "Studies of College Attrition: 1950-1975." Review of Educational Research, 48, No. 1 (1978), 49-101.

Spiegel, Murray R. Schaum's Out line of Theory and Problems of Statistics. San Francisco: McGraw-Hill, 1961.

Stinchcombe, Arthur L. Rebellion in the High School. Chicago: Quadrangle Books, 1964 .

Tinto, Vincent. "Dropout from Higher Education: A Theoretical Synthesis of Recent Research." Review of Educational Research, 45 , No. 1 (1975), 89-125.

Tumin, Melvin M. "Some Principles of Stratification: A Critical Analysis." In Readings on Social Stratification. Ed. Melvin M. Tumin. Englewood Cliffs, N.J.: Prentice-Ha11, 1970, pp. 378-386.

Tumin, Melvin M. "Reply to Kingsley Davis." In Readings on Social Stratification. Ed. Melvin M. Tumin. Englewood Cliffs, N.J.: Prentice-Hall, 1970, Pp. 392-393.

Tumin, Melvin M. "On Inequality." In Readings on Social Stratification. Ed. Melvin M. Tumin. Englewood Cliffs, N.J.: Prentice-Ha11, 1970 , Pp. 400-408.

Van Den Berghe, Pierre L. "Dialectic and Functionalism: Toward a Theoretical Synthesis." In Sociological Theory. Ed. Walter L. Wallace. Chicago: Aldine Publishing Co., 1969, 202-212.

Wilson, A. B. "Residential Segregation of Social Classes and Aspirations of High School Boys." In Class, Status and Power. Ed. Bendix and Lipset. New York: The Free Press, 1966, Pp. 335-342.

INSTITUTIONAL REPORTS

Burgess, T. C. "The Study of Student Attrition at PSU: A Two Year Follow-up." Research Reports, 4, No. 10. Counseling Center, PSU. 1969. 
Capsules: A Review of Higher Education News and Research, 4, No. 29, (1975), p. 1090 .

Daugherty, Terrence S. "Research in Student Attrition at PSU: Report on Why Students Were Leaving PSU Fall of 1977 and Winter of 1978." Attrition Report No. 4. Report No. 2-79. Office of Institutional Research, PSU, 1979.

- "Research in Student Attrition at PSU: Update Report on Attendance Patterns of Students First Entering PSU Fall 1971." Attrition Report No. 3. Report No. 2-78. Office of Institutional Research, PSU, 1978.

"Why Students Choose to Stop-Out Temporarily or Permanently from PSU." Attrition Report No. 2. Report No. 4-77. Office of Institutional Research, PSU, 1977.

"Research in Student Attrition at PSU: When Students Are Most Likely to Leave School and Not Return." Attrition Report No. 1. Report No. 5-76. Office of Institutional Research, PSU, 1976.

Florida International University. Analysis of Fall 1974 Withdrawals. FIU, 1975.

Haas, P. Follow-up Study of Discontinuing Students at Indiana University at South Bend. IU, August, 1974.

Iffert, R. E. and B. S. Clarke. College Applicants, Entrant s, Drop Outs.Report \#0E54034. Office of Education, Washington, D.C., 1965 .

Kamens, D. H. The Effects of College on Student Drop Out. Center for Applied Social Research. Northeastern University, August, 1972.

Kinnick, Mary and J. Huebner. Entry and Movement Characteristics of Samples of University of Colorado Students: A Descriptive Analysis. Office of Institutional Research, University of Colorado, Nov., 1972.

Lavin, D. E. Student Retention and Graduation at the City University of New York: September 13 Enrollees Through 7 Semesters. New York Office of Programs and Policy Research, CUNY, August, 1974.

Ricks, Mary. "Drop-Outs From PSU: A Study of Students Leaving School During Fall Term, 1978." Report No. 6-79. Office of Institutional Research, PSU, 1979.

Timmons, R. F. Personality and Demographic Factors Associated with Freshman Withdrawal from College. Dept. of Psychology, University of Colorado, 1972 . 
Womack, R. and J. McCluskey. Characteristics and Perceptions of Nonreturning Students at Arkansas State University. ASU, Spring, 1973.

\section{COMMUNICATIONS AND PAPERS}

Farine, A. Demographic and Social Accounting: A Follow-Up on the Withdrawals from Quebec Colleges. A paper presented at the annual meeting of the American Educational Research Association. New Orleans: Feb.-Mar., 1973.

Hillery, Milton. "Institutional Future - Stumbling Blocks or Stepping Stones?" 1981 Portland Community College Advising Workshop, Portland, Oregon. May 22, 1981 .

Jensen, Eric L. "Student Aid in Higher Education: A Review of the Effects on Student Achievements." Unpublished paper presented at the 1980 Pacific Sociological Association. San Francisco: April, 1980 .

Lenning, 0scar. Letter to Mary Rinnick, OIR Administrator, PSU, 1975.

Savage, Barry. Several personal conversations regarding the topic of attrition. 1978-1979. 
APPENDIX A

THE STUDENT QUESTIONNAIRE 
The following questionnaire is the basic instrument used in the gathering of data for this thesis research. There were minor variations in the tense and terminology of some questions due to the different characteristics of Reed College and Portland State University as well as differences between continuing and nonreturning students. Reed College operates on a semester basis whereas PSU operates on a quarter basis. Past tense was often used as a reference to college experiences for the nonreturning students and present tense was used for continuing students. Nonreturning students were asked why they left school. They were also asked to give their future academic plans. These questions were not asked of the continuing students. All other elements of the questionnaire were the same. The Portland State University nonreturning student questionnaire is presented in this appendix. 
We invite your participation in this study and feel that results will be of benef it to current students and to yourself. We are in the midst of a project designed to better understand why students are leaving college before achieving a degree. The responses of students who did not return after Fall quarter will be compared to those who did return to increase our understanding of why college students are leaving school. Your name is not asked for on the survey to ensure the confidentiality of your responses. The survey is printed on both sides of the paper. A post-paid envelope for the return of the questionnaire is attached. Please return this survey as soon as possible.

Office of Institutional Research, PSU (229-3432)

If you have graduated please check the following box and return the questionnaire unanswered.

I have graduated ...... $\square$

1. Age:

2. Sex: (1) Male

3. Marital Status:

(1)

(2) Female

4. Number of dependents (not including spouse):

5. Briefly state your major reason for leaving school after Fall term:

6. What was your class level when you last attended school:
(1)
(2) Freshman
(3) Sophmore
(4) Junior
(5) Senior Not sure

7. How long have you been attending this school:
(1) One quarter
(2) Less than a year, but more than one quarter
(3)__ One year or more, but less than two years
(4) Two years or more

8. Please state your major when you were attending college:

9. What are your future academic plans:
(1) Return to this school within the year
(2) Return to this school sometime in the future
(3) Attend college somewhere else
(4) Not return to college
(5) other. Specify : 
10. When you entered college what was your primary degree objective:

(1)_Did not have earning a degree as an objective

(2)_Build up credits to transfer to another school

(3)_Achieve a Bachelor's degree

(4) Other

11. Do you intend to enter a Post Graduate school after receiving a Bachel or's degree?
(1)
(2)
Yes No

12. Are you or have you been a member or participant in any of the following college organizations or activities? (Please mark all that apply):

Sororities or fraternities

Athletics

Other extra curricular activities. Specify:

Campus clubs. Specify:

other. Specify:

13. What were your living arrangements while attending school:
(1)
(2) Near campus residence (within walking distance)
(3) Off campus residence with parents
(4)_Other of campus residence. Specify:

14. What proportion of your friends are currently college students:
(1)
(2)
(3) A $\mathrm{few}$
(4) Some Most A11

15. What was the nature of your employment status when you were attending school:
(1)
(2) Not working
(3) Working part time Working full time

16. Where was your place of work when you were attending school:
(1)
(2) On campus
(3) Off campus Not working

17. Was your work related to your academic goals:
(1)
(2) Not working
(3) Not related at all
(4) Partially related

18. Please state your approximate college grade point average: 
19. What was the intensity of your interest in your major area of study:
(1)
(2)
None
(3)
Slight
(4) Moderate Great

20. What do you feel your chances are of obtaining employment in your area of study once you receive a degree:
(1)
(2) Poor
(3) Average Good

21. What was your approximate high school grade point average?

22. What is your father's highest level of education:
(1) Grade $8 \mathrm{chool}$
(2) High school
(3) Some college
(4)_Bachelor's degree
(5)_Post graduate

23. What is your mother's highest level of education:
(1)_Grade school
(2) High school
(3) Some college
(4) Bachelor's degree
(5)_Post graduate

24. What is your father's occupation:

25. Rank the three most important sources of financial support as they related to your expenses while attending college. Place a " 1 " in the space next to the greatest source of support, a " 2 " in the next greatest, and a " 3 " in the third most important source of financial support.

Parents
Spouse
Grants
Loans
GI bill
Scholarships
Personal savings
Employment
Work study
Wother. Specify :


26. What is the approximate combined income of your parents for the previous year:
(1)
(2) $\$ 8,000$ or less
(3) $\$ 8,001$ to $\$ 15,000$
(4) $\$ 15,001$ to $\$ 20,000$
(5) $\$ 20,001$ to $\$ 25,000$
(6) $\$ 25,001$ to $\$ 35,000$
(7) $\$ 35,001$ to $\$ 40,000$
(8) $\$ 40,001$ to $\$ 50,000$ Over $\$ 50,000$

27. What was your approximate personal (include spouse) income for the previous year:
(1) $\$ 1,000$ or 1 ess
(2) $\$ 1,001$ to $\$ 3,000$
(3) $\$ 3,001$ to $\$ 5,000$
(4) $\$ 5,001$ to $\$ 7,000$
(5) $\$ 7,001$ to $\$ 10,000$
(6) $\$ 10,001$ to $\$ 15,000$
(7) $\$ 15,001$ to $\$ 20,000$
(8)_Over $\$ 20,000$

28. Please list a few of the most positive and most negative aspects of your experiences at the last school you attended: (continue on back)

Most positive:

Most negative: 


\section{APPENDIX B}

THE QUALITATIVE RESPONSES OF PSU NONRETURNING STUDENTS AS TO WHY THEY LEFT SCHOOL 
The following are the qualitative responses of Portland State University students to the request, "Briefly state your major reason for leaving school." The responses are presented exactly as the students wrote them. 
0000 To work full time.

0001 Marriage

0002 Financial aid not available to widows with responsibilities.

0003 Ful1-time job.

0004 Accounting internship through PSU.

0005 Lack of money.

0006 Had a better offer to go to another school, somewhere were you feel like a person, and not just a loner walking arond the haus.

0007 Got married.

0008 Loss of financial aid award.

0009 I was dissatsified with my major and was undecided as to what field I would then like to pursue.

0010 Need for full time work so as to provide for further education.

0011 I was ill Winter quarter, but I'm not coming back. Right now I'm looking for work.

0012 I transferred to Oregon State University.

0013 To straighten out my life a bit.

0014 Ran out of money. Working two jobs to go back.

0015 Did not like PSU.

0016 No money.

0017 I felt that I didn't really know what I wanted there. So I wanted to start working.

0018 ski racing.

0019 To earn some extra money.

0020 I couldn't afford it. Didn't need too many of winter term classes for graduation.

0021 I haven't really less hours, grant $w /$ held.

0022 Expiration of G.I. bill and desire to return to full time work. 
0023

0024

0025

0026

0027

0028

0029

0030

0031

0032

0033

0034

0035

0036

0037

0038

0039

0040

0041

0042

Work full time - subjects didn't interest me.

Wanted to work so I could go to another school Fall of 178.

I couldn't afford to stay; needed a full-time job.

Bad social atmosphere.

Financial.

Attend another university.

Unable to decide on major; General unhapiness, lack of enjoyment. Need money to afford marriage.

I wanted to spend more time with my 9 month old son.

I was bored with my classes. I didn't know what I wanted to major in. And I got tired of riding the bus.

A mysterious guilt for wanting to pull out, just at the last moment before being a success, and laughing at one's self, future, and past struggles.

Car accident - required two months bed recuperation.

Portaland State was a nice enough school. I enjoyed my teachers and classes. The tuition was rather high though, and when my basic grant fell through I couldn't afford tuition on my own. Now I have been going to Clackamas Comm. College in Oregon City. This is my third term there because I went there last year. It is al so a nice school, but in three terms I feel I have exhausted their art department resources. I may go to PSU again next Fall. It depends on the grants.

Transferred to $U$ of 0 .

The school didn't offer the courses at night that I wanted - I have to work during the day.

School hours conflicted with working hours.

Over-seas business trip and "building" my own home.

To many activities to devote enough time to studies.

Lack of funds.

Returned to UOHSC School of Nursing.

Earn enough money to support myself after reentry to school for Spring term. 
0043 Disillusioned with the Education Department.

0044 I started working full time.

0045 I had just got out of H.S. and went right back to 8 chool fall term. I liked it, but it didn't seem to be where it was at for me right now, although I plan to go back in the future.

0046 I went to University of Oregon school of Nursing.

0047 Went to Europe. In school $i$ felt too confined and $i$ wanted to free lance in writing.

0048 PSU did not offer the course I wanted to take and didn't have an atmpsphere that was good for studying. I did not leave college. I am attending another.

0049 Moved.

0050 I transferred to sosc.

0051 I ran out of money and the $8 \mathrm{chool}$ (PSU) was out of NASL money.

0052 Couldn't handle both work and school full time. Never learned to study properly.

0053 I was considering changing may major and was unsure as to which direction to follow. I wanted some time to think about it and to get some work in on the side.

0054 Not enough money to go to $8 \mathrm{chool}$.

0055 PSU Ed. department lost my student teaching app.

0056 I checked with my advisor and he told me what classes I needed to graduate and so I took them Fall term thinking $I$ was to graduate in Mar. and then I got a letter stating what to do for graduation on Mar. 16. Then I called up and a lady in records said I wasn't done - I had 32 hours left. My advisor though said I was thru. That's why I left. I had a job all set up when I graduated, but then I couldn't have the job. So I am now at a different school to finish.

0057 Transferred to another school.

0058 Am pregnant and need to work full time to save up enough money.

0059 Time and distance required for commuting from home to school (100 miles daily). 
0060 I was not in need of a grant or work study according to them, so I didn't have enough money to finish. I had to get a job.

0061 Went to work so I could earn some money to move into an apartment. Also I just needed a break from school. I am now going to school at PSU full time this term (Spring).

0062 I was hospitalized for extensive reconstructive surgery to my knees from a skiing injury. The main reason I don't finish the few remaining classes necessary for my degree lies with my plans to continue taking classes without having to pay graduate fees, which are nearly triple.

0063 Initially set out to get a full degree (bachelors) in civil engineering. After spending $1-1 / 2$ years at PSU I found that it was becoming financially impossible for me to complete my full degree and also support my family.

0064 Went sking.

0065 Was offered a wrestling scholarship at Clackamas Community College.

0066 I, myself, wasn't ready for college - it has nothing to do with the college. I just wasn't ready at the time. I am however planning on trying it again this fall.

0067

Atmosphere of school was too cold and unsociable.

0068

0069 I ran out of money.

0070 Because I don't have enough money to continue the next term. Also, I had an accident with the other car 1 week before final exam for the fall term. So I need to go to work.

0071 No interesting classes. Too many Arabs.

0072 To save money to attend University of Oregon Fall 1978.

0073 Family illness.

0074 I tried to schedule all morning classes, which would afford me the opportunity to work an 8 hour day, but was unable to get the classes I selected.

0075 Enrolled at other University.

0076 Extremely difficult to maintain FT employment and classload and do either well. 
0077 Got married, bought house, settled down.

0078 I transferred to Linfied College.

0079 Employment opportunity in my field of interest (Political Science) Government program for a year in Wash. D.C.

0080 I wanted to go to a school with a friendlier atmosphere. Also I wanted to get away from home.

0081 I missed the first three weeks of Winter term and my parent's needed the money.

0082

0083 I participated in the Reserve Component of the US Army. I have been on active duty for the past 4 months. Basic Training and schooling.

0084

0085 I didn't want to go to school anymore.

0086 I just wasn't cut out for going to school. It just isn't my thing.

0087 Travel.

$0088 \quad$ Temporary employment.

0089 To return to my favorite place.

0090 I am presently attending school.

0091 To participate in a field project in Arizona. Will return Fal1 178 .

0092 I was becoming bored with school. Not attending classes. This irritated my teachers and only...

0093 I enrolled in another program to study in Spain in the Spring.

0094 I was planning to leave in January to travel abroad.

0095 Travel in foriegn country. 


\section{APPENDIX C}

THE QUALITATIVE RESPONSES OF REED NONRETURNING STUDENTS AS TO WHY THEY LEFT SCHOOL 
The following are the qualitative responses of Reed College students to the request, "Briefly state your major reason for leaving school." The responses are presented exactly as the students wrote them. 
2000 The very poor atmosphere at Reed, close regulation (though many there need it) and living conditions. I decided to transfer to a more conservative school.

2001 The mental anguish I was suffering did not seem worth the large expenditure necessary to enroll spring term.

2002 Needed a vacation without job or studying for a short while. Got to visit a foreign country.

2003 I did not feel I was benefiting myself or the school.

2004 I wanted to get my feet on the ground and do something real in the world.

2005 Financial disability to return.

2006 Pressures in personal life.

2007 I left temporarily for medical reasons. I plan to return this fall.

2008 Dissatisfaction.

2009

$2010 \quad$ Psychotic Episode.

2011 To attend PSU full time and practice jazz guitar 3 to 5 hours a day.

2012 Anxiety (self-direction, family problems, life).

2013 I had accomplished everything I wanted out of Reed; I also decided that academia was not for me.

2014

2015 Various emotional and academic reasons.

2016 To go to school in home-town with major in Engineering, possibly.

2017 Reasons many and varied...came to conclusion I was wasting my time.

2018 I was lonely and unhappy at Reed college.

2019 Didn't want to get down to studying yet.

2020 Career related job opportunity with an Archaeological Museum. 
After two years it seemed apparent that being at Reed was bringing me more grief than happiness. The extreme and relentless demands of academics as well as the marked lack of personal recognition or feeling of accomplishment created a destructive level of anxiety in me that I feel severely impeded my academic progress.

2022 Reed's academic and social enviroment is unhealthy.

2023 Financial crises - Separation from loved ones led to depression.

2024 My mother died, and I felt I just couldn't go on.

2025 Dissatisfied with level of teaching and bored.

2026 The science program was not geared for pre-med due to its high caliber and extraordinary competition; The religion department (my major) was not oriented toward the ministry. My plans are to be medical missionary. Also, Reed's reputation, although good academically, is also one of wild and radical

characteristics which is not what I want.

2027 Was depressed, tired of school and displeased with my major.

2028 Attending Reed I grew up and out. I began to realize there was a whole world around me that I was unaware of. That's why I eventually left Reed. My priorities changed. I also blew the last semester I was there, academically, but not personally.

2029 Disillusioned with "liberal arts" ideal, and second thoughts as to my true chances of entering graduate school. Maybe a technical school is more practical.

2030 Personal problems and a 1088 of interest in academics.

2031 Too tired to handle load necessary to graduate.

2032 Needed some breathing time between intense academic semesters. Also, I have only 3 semesters left ( 1 until thesis year) and I wish to take some specific courses at another school in the fall of the following year.

2033 Academic burn-out; I'm long over-due for a break. 2034 Having to pay tuition forced me too hard causing GPA to drop. 